\title{
Are CSR Disclosures Value Relevant? Cross-Country Evidence
}

\author{
Steven F. Cahan ${ }^{1}$, Charl De Villiers ${ }^{2,3}$, Debra C. Jeter ${ }^{4}$, Vic Naiker ${ }^{5}$ \\ and Chris J. Van Staden $6,{ }^{*}$
}

\begin{abstract}
${ }^{1}$ Department of Accounting and Finance, University of Auckland, Auckland, New Zealand, 2Department of Accounting, Auckland University of Technology, Auckland, New Zealand, ${ }^{3}$ Department of Accounting, University of Pretoria, Pretoria, South Africa,

${ }^{4}$ Owen Graduate School of Management, Vanderbilt University, Nashville, TN, USA, ${ }^{5}$ Department of Accounting, Monash University, Melbourne, Australia and

${ }^{6}$ Department of Accounting, Auckland University of Technology, Auckland, New Zealand

*Correspondence Address: Chris J. van Staden, Faculty of Business and Law, Auckland University of Technology, Private bag 92006, Auckland, 1142 New Zealand. Emails: cvanstad@aut.ac.nz, chris.vanstaden@aut.ac.nz
\end{abstract}

\begin{abstract}
Using proprietary data that rate corporate social responsibility (CSR) disclosures of firms in 21 countries, this study examines how the strength of nation-level institutions affects the extent of CSR disclosures. We then examine the valuation implications of CSR disclosures and consider how the relation between CSR disclosures and firm value varies across countries. In contrast to prior studies, we separate CSR disclosures into an expected and unexpected portion where the unexpected portion is a proxy for the incremental information contained in CSR disclosures. We observe a positive relation between unexpected CSR disclosure and firm value measured by Tobin's $Q$. We also find that, while countries with strong nation-level institutions promote more CSR disclosures, the valuation of a unit increase in unexpected CSR disclosures is higher when nation-level institutions are weak.
\end{abstract}

\section{Introduction}

Proactive strategies in the area of corporate social responsibility (CSR) are becoming a 'business imperative' (Kanter, 2011). As early as 1990, Fombrun and Shanley (1990) argue that CSR enhances a firm's reputation, leading to greater goodwill and better economic performance in the long-run. Using US data, Dhaliwal, Li, Tsang, and Yang (2011) find that 
firms that initiate a stand-alone CSR report and exhibit superior CSR performance have a lower cost of capital, suggesting that CSR disclosure is an important channel for informing investors about CSR performance. In this study, we complement Dhaliwal et al. (2011) by examining the association between CSR disclosure and firm value in 21 countries. Further, relative to Dhaliwal et al. (2011 Dhaliwal,), who focus on the presence rather than the content of CSR reports, we use a broad measure of CSR disclosure that encompasses firminitiated information from the firm's websites, stand-alone CSR reports, and annual reports.

The international context of our study is important because loannou and Serafeim (2012) find that corporate social performance is related to nation-level institutions such as the political system, education system, and cultural system. While prior studies have documented a link between CSR performance and CSR disclosures, we are particularly interested in CSR disclosures. CSR disclosure may affect firm value either directly or indirectly. For example, by reducing the information asymmetry between firms and investors, Dhaliwal et al. (2011) find that firms initiating disclosure of CSR activities may attract dedicated institutional investors, raise more equity capital, and attract greater analyst coverage: a direct effect. On the other hand, Elliott, Jackson, Peecher, and White (2014) argue that CSR disclosures can indirectly affect firm valuation by altering investors' perceptions of firm value. Further, these disclosures may serve to provide legitimacy, to build political connections, or to mitigate negative impacts when a firm or other firms in the same industry face adverse publicity (e.g. Blacconiere \& Patten, 1994; Marquis \& Qian, 2014; Matsumura, Prakash, \& Vera-Muñoz, 2014). Whether the channel is direct or indirect, loannou and Serafeim's (2012) findings suggest that the informativeness of CSR disclosures may vary across countries depending on the strength of a country's nation-level institutions.

In addition to using international data and a more comprehensive measure of CSR disclosure, we make two other methodological improvements relative to prior research. First, we estimate the unexpected part of CSR disclosure. We argue that investors have expectations about the extent of CSR disclosure that a firm is likely to provide. These expectations are a function of firm and industry characteristics, as well as the nation-level institutional environment to which the firm is exposed. While prior studies examine 'voluntary' CSR disclosure (e.g. Cho \& Patten, 2007; De Villiers \& Van Staden, 2011), 'voluntary' disclosures may actually be expected by investors or other stakeholders, leading firms to routinely disclose such information. ${ }^{1}$ For example, all firms may voluntarily state that they follow equitable employment practices, which reduces the value of this information for discriminating among firms on the basis of employment practices. Hence, we model expected CSR disclosure and use the difference between actual and expected CSR disclosure (i.e. unexpected CSR disclosure) as a proxy for the informative portion of CSR disclosure.

Second, while prior studies generally examine the relation between CSR disclosures and contemporaneous firm performance (e.g. De Villiers \& Van Staden, 2011; Freedman \& Jaggi, 1988), we focus on the firm's long-term expected value instead of current economic performance since the benefits of superior CSR on firm value are more likely to manifest in the long-run (e.g. Kanter, 2011). Following Daske, Hail, Leuz, and Verdi (2008), Doidge, Karolyi, and Stulz (2004), Jiao (2011), and Lang, Lins, and Miller (2004), we rely on Tobin's $Q$ to measure the market's assessment of a firm's long-term expected value. Tobin's $Q$ 
includes the market's assessment of a firm's future cash flows and the riskiness of those cash flows. Although Dhaliwal et al. (2011) concentrate on the risk portion of this assessment, that is, the cost of equity capital, CSR activity can have cash flow implications. For example, a firm's CSR disclosures may reveal new sustainability-related market opportunities or good relationships with employees and other stakeholders, increasing the market's expectations of future cash flows and Tobin's $Q$. On the other hand, when firms' CSR disclosures do not deal with issues the market would expect, such as environmental management procedures and remediation liabilities for firms in the mining industry, the market can only assume the worse, leading investors to revise their expectations of future cash flows downwards, decreasing Tobin's $Q$.

We conduct our analysis in two stages. First, we model expected CSR disclosures and find that CSR disclosures are greater in countries with stronger nation-level institutions. We use the residual from our first-stage regression to proxy for unexpected CSR disclosure. In contrast to prior research that relies on a self-constructed CSR disclosure index based on a single source, we use proprietary data from KPMG that rate the top 100 firms in 22 countries based on all their CSR disclosures in the public domain, that is, company websites, stand-alone CSR reports, and annual reports. KPMG's disclosure measure covers environmental strategy, stakeholder engagement, corporate management systems, reporting, climate change, supply chain, responsible investment, and assurance; deals with CSR disclosures and disclosure policy rather than CSR performance; and includes aspects that reflect the quality, rather than the quantity, of CSR disclosures (KPMG). ${ }^{2}$ Thus, relative to prior measures of CSR disclosures, the KPMG ratings cover all types of firm-initiated CSR disclosures and capture the content of CSR disclosures as opposed to the presence of a CSR report.

Second, we regress Tobin's $Q$ on unexpected and expected portions of CSR disclosure and find a positive relation between unexpected CSR disclosure and firm value. On the other hand, as expected, we find no relation between expected CSR disclosure and firm value. Our results are robust to controlling for actual CSR performance, and in a change analysis, we find that increases in unexpected CSR disclosure levels are related to increases in firm value. Moreover, we find that the valuation of a unit increase in unexpected CSR disclosures is higher in countries with less democracy, less press freedom, less commitment to an environmental agenda, and weaker institutions in general. Firms in countries with strong nation-level institutions are watched more closely by investors and are under greater pressure to release more qualitative and quantitative information. Thus, even though firms in these countries provide more CSR information, under these relatively transparent conditions, their CSR disclosures tend to be less incrementally informative than in countries where institutions are comparably weak.

The remainder of this study is divided as follows. The second section discusses background and hypotheses, while the third section describes the sample and research design. The fourth section presents the main results, and the fifth section presents the findings from additional tests. The sixth section is a conclusion. 


\section{Background and Hypotheses}

Accounting researchers have long been interested in firms' disclosures about their CSR initiatives (e.g. see Ingram \& Frazier, 1980; Wiseman, 1982, for early evidence). Yet, the credibility of these disclosures remains in question, and it is unclear whether managerial disclosures related to CSR are value relevant. Prior research has attempted to shed light on the usefulness of CSR disclosures by examining the relation between CSR disclosure and firm performance, but those studies yield mixed results. For example, prior studies have shown a positive, negative, or no relation between CSR disclosure and firm performance (e.g. Clarkson, Fang, Li, \& Richardson, 2013; De Villiers \& Van Staden, 2011; Freedman \& Jaggi, 1988; Plumlee, Brown, Hayes, \& Marshall, 2015).

\subsection{Related Literature}

Since disclosures are potentially costly (e.g. Verrecchia, 1983), managers only disclose information voluntarily if the benefits outweigh the costs. The benefits of voluntary disclosures include reducing information asymmetry and adverse selection costs (e.g. Healy \& Palepu, 2001), and increasing investor awareness, leading to a potentially larger investor base (e.g. Merton, 1987). Further, additional disclosures can reduce estimation risk as investors will be better able to estimate the parameters of firms' underlying cash flows (e.g. Lang \& Maffett, 2011). At the same time, managers have incentives to act opportunistically when making voluntary disclosures (e.g. Verrecchia, 1990). For example, Healy and Palepu (2001) identify poor performance as an incentive for chief executive officer to use voluntary disclosures to justify or mitigate the impact of disappointing results. Merkl-Davies and Brennan (2007) refer to 'impression management' where managers exploit information asymmetries by engaging in biased reporting.

Studies that examine the relation between CSR disclosures and contemporaneous economic performance yield mixed results and have largely focused on environmental disclosures. Freedman and Jaggi (1988) examine the association between the extent of pollution disclosures and current economic performance of firms in four highly polluting industries. Using a disclosure index to measure the extent of disclosure and choosing return on assets (ROA) and return on equity as their measures of performance, they find no significant association between contemporaneous economic performance and pollution disclosures for their total sample. However, when they segment the sample by industry and size, they observe some significantly negative associations.

More recently, De Villiers and Van Staden (2011) find that economic performance (measured using ROA) is negatively related to environmental disclosures in the annual report, while Clarkson et al. (2013) find that voluntary environmental disclosures in the five most polluting US industries are incrementally informative relative to toxic emissions data and that investors seem to use emissions data to assess firms' risks. Similarly, in another study examining US firms, Plumlee et al. (2015) present evidence consistent with an association between voluntary environmental disclosure quality and a firm's cost of equity capital and expected future cash flows. 
Dhaliwal et al. (2011) attempt to look beyond the environmental aspect by focusing on stand-alone CSR reports. They examine whether firms that voluntarily initiate such a report benefit from a decline in their cost of capital. They find that firms with a high cost of capital tend to initiate a stand-alone CSR report and that, subsequently, they experience a reduction in the cost of equity capital under certain conditions. Dhaliwal et al. (2011) use a binary indicator to capture the presence or non-presence of a stand-alone report. In contrast, we use a continuous measure related to the content of all CSR disclosures.

Simnett, Vanstraelen, and Chua (2009) examine the characteristics of firms that issue sustainability reports and voluntarily have them assured. They use an international sample drawn from 31 countries. Simnett et al. (2009) find that firms that have a greater need to enhance the credibility of their reports seek assurance. They find that firms in stakeholderoriented countries (i.e. code law countries) are more likely to have their reports assured than firms in shareholder-oriented countries (i.e. common law countries). Dhaliwal, Radhakrishnan, Tsang, and Yang (2012) use international data and find that CSR reports are more informative for analysts in stakeholder countries. We follow these two studies and employ cross-country data. However, rather than focusing on the assurance aspect or the effect on financial analysts, we re-examine the association between CSR disclosure and firm value.

In conducting our tests, we emphasize that we are interested in CSR disclosure rather than CSR performance per se. That is, we examine how the extensiveness of voluntary CSR disclosures leads to economic benefits in terms of higher firm value. The extant literature suggests several channels through which this association may occur. First, if CSR disclosures portray the firm's real environmental and social performance, that is, they are credible, CSR disclosures should reduce the information asymmetry between firms and their investors. However, if CSR disclosures are opportunistic or unappreciated by the market, CSR disclosures could be unrelated, or even negatively related, to firm value. In Dhaliwal et al. (2011), firms that initiate a stand-alone CSR report and exhibit superior CSR performance (credible reporters) experience a decline in the cost of capital in the subsequent year. Initiating firms with superior social responsibility performance attract dedicated institutional investors and greater analyst coverage, and raise larger amounts of equity capital than noninitiating firms. Firms that initiate a stand-alone CSR report and have inferior CSR performance (opportunistic reporters) do not experience a decline in cost of capital in the subsequent year. These findings suggest that users are able to distinguish between credible and opportunistic reporting. ${ }^{3}$

Second, CSR disclosure could be related to investor demand, especially with the growth in socially responsible investing where institutions use filters based on CSR information. Hong and Kacperczyk (2009) show that, consistent with Merton's (1987) theory on neglected stocks, firms shunned by institutions for socially related reasons trade at a discount. By the same token, firms that meet the criteria of socially responsible investors experience greater investor demand, leading to higher firm value. Similar to Fang and Peress (2009) who use Merton's (1987) theory to explain why firms that receive no media coverage trade at a discount, for any level of CSR performance, poor (good) CSR disclosure can reduce (increase) investor awareness and investor demand. For example, Matsumura et al. (2014) find that in addition to a penalty imposed by the market for firms' carbon emissions, firms that do not 
disclose their carbon emissions face a further penalty for their failure to disclose. Using carbon emissions data from 2006 to 2008 and correcting for self-selection bias, Matsumura et al. (2014) present evidence that the median value of disclosing firms is approximately $\$ 2.3$ billion greater than that of comparable non-disclosing firms in their sample. They conclude that the voluntary disclosure, in addition to the carbon emissions themselves, affect firm value. Bialkowski and Starks (2015) report that $18 \%$ of the assets under professional management are in funds that follow socially responsible investing practices, suggesting the need for voluntarily disclosed information about CSR is high.

Third, using theoretical and experimental evidence, Elliott et al. (2014) suggest higher fundamental value estimates when investors are exposed to, but do not explicitly assess, positive CSR measures, with a decrease when the assessment is more explicit. They conclude that the impact on firm value is unintentional, and that the effect of this unintentional influence is to raise the amount an investor is willing to pay for stock in a firm believed to have positive CSR. Elliot et al. (2014, p. 279) regard CSR disclosures as 'vivid and imagery provoking' and suggest that these disclosure 'reveal corporate values' that could be aligned (or misaligned) with investors' views about proper firm behavior, thereby having an unintended valuation effect.

Fourth, CSR disclosure could also provide 'insurance' when a firm is facing negative publicity or spillover effects from industry-wide operational risk concerns. Blacconiere and Patten (1994) examine the reaction of the market to chemical firms other than Union Carbide to a 1984 leak in India that resulted in over 200,000 injuries and about 4000 deaths. They find evidence of a significant negative intra-industry reaction in reaction to the leak. However, firms with more extensive environmental disclosures in their financial report prior to the chemical leak experienced a less negative reaction than firms with less extensive disclosures. They conclude that investors interpret a firm's disclosures as a positive signal regarding its management of risks and exposure to future regulatory penalties.

Finally, Marquis and Qian (2014) examine the CSR reports of 1600 Chinese firms between 2006 and 2009 and develop a political angle suggesting that CSR communication serves a legitimating function. They consider the firms' dependency on government monitoring and argue that firms that are more dependent on the government are more likely to issue CSR reports, as are firms in situations in which they are more likely to be monitored. Building political connections in these situations may lead to increased firm value.

In summary, all these studies suggest that, in various contexts and through differing channels, CSR disclosures are important and are taken into account in assessing firm value by investors and markets.

\subsection{Hypotheses}

loannou and Serafeim (2012) find that a firm's performance in the social arena depends on the nation-level institutions of the country in which it operates. However, they do not consider the economic benefits that accrue to good social performers, and to do so, one needs to consider how information about corporate social performance gets transmitted to investors and other stakeholders. Firm-initiated disclosures can potentially provide 
important information about a firm's CSR activities and allow stakeholders to assess the firm's performance relative to its peers (e.g. Radley Yeldar, 2012).

Extending loannou and Serafeim (2012), we expect that the demand for CSR disclosures will depend on the orientation and strength of nation-level institutions. For example, as Simnett et al. (2009) and Dhaliwal et al. (2012) suggest, we expect that where stronger enforcement measures have been institutionalized over time, investors would be relatively more demanding of (and more successful in) receiving corporate information about CSR activity. Similarly, in countries where investors and the general public have been able to establish strong political accountability and strong media freedom, stakeholders would likely be more demanding in terms of corporate CSR accountability. Therefore, we expect firms in countries with stronger accountability through both political and media mechanisms to respond to greater accountability demands from investors and the general public by providing higher levels of CSR disclosure. We predict a positive relation between the CSR disclosure level and measures of the rule of law (greater respect for and enforcement of laws), citizens' voice and accountability (the ability to elect government and voice their concerns), government effectiveness, regulatory quality, and press freedom.

Even if investors in countries more committed to sustainability concerns are not particularly interested in these issues, the higher level of public commitment to sustainability ideals may be expected to lead to greater scrutiny of firms' sustainability impacts and to greater adverse financial impacts should firms overstep the mark. These impacts can take the form of direct fines, consumer boycotts, and other forms of resource withdrawal, for example, withdrawal of political support, that can have far ranging financial impacts. Such cash flow impacts will be of concern to investors, who thus become more demanding with respect to CSR information in order to form their own risk assessment.

Therefore, we expect a positive relation between CSR disclosure levels and nation-level measures of institutional strength and commitment to sustainability and environmental performance. This leads to our first hypothesis:

Hypothesis 1: Firms disclose more CSR information in countries with stronger nationlevel institutions including democracy, press freedom, and commitment to the environment.

Prior studies link better CSR performance to a variety of benefits with the potential to increase financial performance. These include increased sales (Lev, Petrovits, \& Radhakrishnan, 2010), recruitment of superior quality employees (Edmans, 2011), more favorable treatment by regulators and policy-makers (Brown, Helland, \& Smith, 2006), and lower cost of equity capital (Dhaliwal et al., 2011). Kanter (2011) explains the causal link between CSR initiatives and financial benefits by stating that firms pursue CSR initiatives to address societal and employee concerns, arguing that being socially responsible leads to stronger financial performance as the firm establishes itself in a leading position. In addition, value-enhancing CSR activities can reduce the risk of future CSR-related negative cash flows and liabilities (e.g. environmental spills). 
Firms provide information about their CSR initiatives by providing CSR disclosures. Firms with superior CSR performance have incentives to provide higher levels of CSR disclosures to distinguish themselves from low CSR performing competitors. Survey evidence also shows that CSR disclosures are the preferred source of information for investors and analysts, specifically the social and environmental information in the sustainability sections of corporate websites and in corporate sustainability reports (De Villiers \& Van Staden, 2010; Radley Yeldar, 2012). Further, the demand for information about CSR is increasing with the growth in socially responsible investing as CSR-related information is needed to screen firms and to apply CSR-related filters. Thus, if investors find CSR disclosures informative (i.e. credible), we expect a positive relation between the incremental information in CSR disclosures and firm value. On the other hand, if CSR disclosures are seen as windowdressing (i.e. opportunistic), CSR disclosure and firm value would be unrelated or negatively related. ${ }^{4}$

As discussed previously, our measure of CSR disclosure is based on the unexpected component of CSR disclosure which is a proxy for the informative portion of CSR disclosure. To further explain, we provide some hypothetical examples of unexpected CSR disclosure. Firms in environmentally sensitive industries, such as oil and gas, tend to disclose more environmental information. This is because prior environmental disasters have led to major financial consequences, with the result that the market now expects firms in these industries to disclose how they deal with environmental matters, including procedures to minimize the possibility of oil spills and other forms of environmental liability (Patten, 1992). Should a firm in this industry disclose less environmental information than the market expectation, market participants will have less information to inform their assessment of this firm's future prospects relative to its industry peers. Market participants can only protect themselves by lowering their estimate of the firm's future cash flows and increasing their estimate of its risk profile (adverse selection). Another example is that CSR disclosure is a much more prominent feature in, say, the UK than in Australia (KPMG, 2011). Thus, even though an Australian and UK firm may have the same level of total CSR disclosure, the former is likely to benefit more than the latter because the market will have more information to inform its assessment of the Australian firm's future cash flows and risk relative to other firms in that country. Nevertheless, whether or not unexpected CSR disclosures are informative is an empirical question. Consequently, our second hypothesis provides a test of the information view:

Hypothesis 2: Firms with more unexpected CSR disclosure are likely to be associated with higher firm values.

Given our hypotheses that nation-level institutional factors influence the level of CSR disclosure and that superior CSR disclosures are associated with higher firm values, we are also interested in how these factors interact. Specifically, is there a difference in the relation between firm value and CSR disclosure in different countries? And, if there is such a difference, in what type of country is the relation between firm value and CSR disclosure stronger?

Dhaliwal et al. (2012) find the positive relation between CSR disclosure and analyst forecast accuracy to be stronger in countries with greater financial opaqueness. In hypothesizing this 
relationship, they argue that CSR disclosures provide more valuable incremental information beyond financial disclosures in such countries, information that assists analysts in making better forecasts (Dhaliwal et al., 2012). This argument can be extended to the relationship between CSR disclosure and firm value. The additional information provided by unexpected CSR disclosure allows investors to improve their valuation of the firm and is likely to be more valuable in countries where information, both financial and nonfinancial, is generally more opaque, that is, countries with weaker institutions, less democracy, less press freedom, and a lower level of commitment to the environment.

In contrast, firms in countries with strong institutions are more closely watched by investors and therefore under greater pressure to release more information. As a result, their CSR disclosures may be less informative. However, the possibility also exists that due to the heightened scrutiny, firms in these countries are less likely to resort to window-dressing and more likely to disclose truthfully. Following Marquis and Qian (2014), an alternative theoretical argument is that, in countries where national institutional strength is low and CSR disclosure is less common, firms are more likely to seek to build political connections, which in turn potentially lead to larger increases in firm values. Since the direction of the relation is unclear, we state the following non-directional hypothesis:

Hypothesis 3: The relation between firm value and unexpected CSR disclosure differs between countries depending on the strength of nation-level institutions including democracy, press freedom, and commitment to the environment.

\section{Sample and Research Design}

\subsection{Sample}

Our original sample is based on 2170 firms from 22 different countries that were assessed by KPMG in 2008 for CSR disclosures. Compared to prior studies that focus on a single location for CSR disclosure, KPMG considered all relevant information in the public domain company websites, stand-alone CSR reports, and annual reports - in developing their CSR disclosure score for each firm. Further, the KPMG ratings are attractive because KPMG had prior experience in conducting such surveys (the ratings we use are the fifth set produced by KPMG), garnered widespread participation across countries, standardized the data collection process on a global basis, and used local staff to circumvent language issues and to ensure that all relevant CSR disclosure information was captured.

We use the 2008 KPMG rating because the 2008 survey is more detailed and includes more items than the more recent 2011 KPMG survey. Specifically, the 2008 survey covers 87 disclosure items while the next survey conducted in 2011 covers only 15 disclosure items. ${ }^{5}$ According to KPMG, the 2008 survey included questions about disclosure related to environmental strategy, stakeholder engagement, corporate management systems, reporting, climate change, supply chain, responsible investment, and assurance (KPMG, 2008). Thus, the 2008 scores provide a richer and more comprehensive picture of the CSR disclosure practices of our sample firms. However, for our changes analysis, we do utilize the 2011 ratings. For these tests, we adjust the 2008 CSR disclosure scores to be comparable to the 2011 scores in a procedure that we describe later. 
It is important to note that the questions in the 2008 KPMG questionnaire focus on the process used to communicate with stakeholders regarding CSR - for example, 'What are the means used by the company to interact with its key stakeholders ... ?', 'Is the company involved in an informal (reactive) stakeholder dialogue?', 'Does the company publicly respond to stakeholder's feedback?' - as well as policies related to CSR - for example, 'Is corporate governance specifically linked to sustainability?', 'Who is primary responsible of $\mathrm{CR} /$ Sustainability management within the company (e.g. Who reports into the Board)?', 'Who is responsible for addressing any infractions against the Code of Conduct?' In contrast, there are no questions that require an actual evaluation of CSR performance. For instance, the questionnaire asks 'Does the company disclose its carbon footprint?' rather than 'Has the company reduced its carbon footprint?' or 'How does the company's carbon footprint compare with its competitors?' Thus, the KPMG ratings reflect how companies formulate and disclose CSR-related information rather the firm's CSR performance per se.

One issue with the KPMG ratings is that they focus on the largest 100 firms in each country. However, since these firms are likely to be the most active in terms of CSR, we believe they provide an interesting and powerful setting for conducting our tests. A second issue is that the KPMG sample includes listed and unlisted firms. For this reason, we delete 1386 firms (including 1047 unlisted firms) that are not covered by Compustat. Prior studies on CSR disclosure also focus exclusively on publicly listed firms. ${ }^{6}$

Next, we delete 108 firms that had insufficient data on Compustat. This results in a final sample of 676 firms from 21 countries for our tests relating to Hypothesis 1 . The additional requirement of daily share price and other financial statement information reduces our sample to 555 observations for the firm value tests related to Hypotheses 2 and 3. To align the measurement of control variables with the approach employed by KPMG in constructing their CSR disclosure scores, our independent variables are constructed using the average of 2007 and 2008 data. Thus, our sample consists of one observation per firm.

Our sample of 676 firms is significantly larger than prior studies examining CSR disclosure. For example, the sample sizes used by Al-Tuwaijri, Christensen, and Hughes (2004), Cho and Patten (2007), Clarkson, Li, Richardson, and Vasvari (2008), Hughes, Anderson, and Golden (2001), and Patten (2002) are 198, 100,191, 51, and 131, respectively. Further, Dhaliwal et al. (2011) have only 213 first-time CSR reports in a sample of 11,925 firm-year observations.

\subsection{Research Design}

As discussed previously, our measure of CSR disclosure is based on the unexpected component of CSR disclosure. Analogous to abnormal or discretionary accruals, we compute the unexpected CSR disclosure by taking the difference between the actual and expected CSR disclosure. Thus, we first model the level of the CSR disclosure. ${ }^{7}$

Clarkson et al. (2008) examine the determinants of environmental disclosure, and we rely on their findings to develop a model of CSR disclosure. The literature in this area rarely uses CSR disclosure as the dependent variable. Of the papers that use CSR or environmental disclosure as dependent variable, Clarkson et al. (2008) incorporate the most comprehensive selection of independent variables (see, e.g. Cho, Freedman, \& Patten, 2012; 
Cho, Roberts, \& Patten, 2010; De Villiers \& Van Staden, 2011). Clarkson et al. (2008) find that firm size, firm performance, financing needs, leverage, and recently acquired assets are significantly related to the level of environmental disclosure. These findings suggest that economies of scale related to information production costs, better economic performance, easier access to debt and equity markets, higher information demands by debtholders, and cleaner technologies associated with newer assets, motivate firms to disclose more about their environment-related investments. They also recognize the possibility of an industry effect and control for industry fixed effects. Other studies in the literature support the findings on these relationships at a more general level while including a less extensive set of control variables in their models (e.g. see Lang \& Lundholm, 1993, on economic performance; Frankel, McNichols, \& Wilson, 1995, on access to debt and equity markets; and Leftwich, Watts, \& Zimmerman, 1981, on leverage).

Although Clarkson et al. (2008) find a strong relation between environmental performance and environmental disclosure, we do not include CSR performance in our main analyses because, with our cross-country sample, we would lose 206 of our 676 observations, which has an adverse effect on the power of our tests, especially some of our additional tests that are performed using our smaller subsections of our sample. Instead, we separately assess the effect of CSR performance on our main findings as part of our additional tests. ${ }^{8}$

While we draw on Clarkson et al.'s (2008) model to identify relevant firm and industry variables to include in our first-stage model, a key difference between their study and ours is that we use cross-country, instead of US, data. As a result, we control for country fixed effects and examine the impact of various nation-level measures of institutional strength on the extent of CSR disclosure provided by firms. Thus, we estimate the following model:

$$
\begin{aligned}
\text { CSRDisc } & =\alpha_{0}+\alpha_{1} \text { Nation-level institution measures }+\alpha_{2} \text { Size }+\alpha_{3} \text { ROA }+\alpha_{4} \text { Fin } \\
& +\alpha_{5} \text { Lev }+\alpha_{6} \text { NewAssets }+\alpha_{7} \text { CapEx }+ \text { Industry indicators } \\
& + \text { Country indicators }+\varepsilon,
\end{aligned}
$$

where CSRDisc is a measure of the total CSR disclosure computed from the KPMG ratings. Each of the 87 items in the 2008 KPMG survey requires a 'yes' or 'no' answer, where a yes (no) response reflects the presence (absence) of the specific disclosure. We code each yes (no) response as a $1(0)$ and compute a total CSR disclosure score (CSRDisc) for each firm where the maximum possible score is 87 .

We use seven different proxies to capture the quality of nation-level institutions and societal concerns across the countries represented in our sample. Table 1 defines the country-level measures in detail and states their expected relationship with CSRDisc. 


\begin{tabular}{|c|c|c|}
\hline Variable & $\begin{array}{l}\text { edicte } \\
\text { sign }\end{array}$ & Variable measurement \\
\hline RuleLaw & + & $\begin{array}{l}\text { Perceptions of the extent to which agents have confidence in, and abide by, the rules } \\
\text { of society, and in particular the quality of contract enforcement, property rights, the } \\
\text { police, and the courts, as well as the likelihood of crime and violence. (Source: World } \\
\text { Bank - http://info.worldbank.org/governance/wgi/mc countries.asp) }\end{array}$ \\
\hline VoiceAcctblty & + & $\begin{array}{l}\text { Perceptions of the extent to which a country's citizens are able to participate in } \\
\text { selecting their government, as well as freedom of expression, freedom of association, } \\
\text { and a free media. (Source: World Bank) }\end{array}$ \\
\hline GovtEff & + & $\begin{array}{l}\text { Perceptions of the quality of public services, the quality of the civil service and the } \\
\text { degree of its independence from political pressures, the quality of policy formulation } \\
\text { and implementation, and the credibility of the government's commitment to such } \\
\text { policies. (Source: World Bank) }\end{array}$ \\
\hline RegQuality & + & $\begin{array}{l}\text { Perceptions of the ability of the government to formulate and implement sound } \\
\text { policies and regulations that permit and promote private sector development. } \\
\text { (Source: World Bank) }\end{array}$ \\
\hline Resplndex & + & $\begin{array}{l}\text { The state of responsible competitiveness - making sustainable development count. } \\
\text { Represents pressure on firms to be sustainable. (Source: Accountability - } \\
\text { www.accountAbility.org) }\end{array}$ \\
\hline EnvrnmtIPerf & + & $\begin{array}{l}\text { Environmental performance index from the point of view of law, policy and science. } \\
\text { (Source: Yale Law School - http://epi.yale.edu/) }\end{array}$ \\
\hline PressFree & + & $\begin{array}{l}\text { Freedom of press measure - a free press promotes governmental accountability. } \\
\text { (Source: Reporters without Borders - http://en.rsf.org/) }\end{array}$ \\
\hline
\end{tabular}

Our first four measures are extracted from the World Bank website

(http://info.worldbank.org/governance/wgi/mc countries.asp). We use the World Bank measures because they are updated regularly and cover a comprehensive set of dimensions (e.g. Kaufmann, Kraay, \& Mastruzzi, 2011). These four measures capture (1) the extent to which agents have confidence in, and abide by, the rules of the society (RuleLaw), (2) the extent to which a country's citizens are able to select their government and voice other concerns (VoiceAcctblty), (3) perceptions of the quality of public services and polices, and the government's commitment to such policies (GovtEff), and (4) perceptions of the government's ability to formulate and implement sound policies (RegQuality). All four measures are allocated values ranging between -2.5 and 2.5 , where higher values reflect a stronger enforcement environment (RuleLaw), higher participation in government selection (VoiceAcctblty), more effective governments (GovtEff), and higher regulatory quality (RegQuality). Based on previous literature, which documents a positive relation between 
strong government institutions and accounting quality (e.g. Bushman \& Piotroski, 2006), we expect all four measures to be positively related to CSR disclosure.

Our next three measures capture societal concerns about CSR issues. The first of these (our fifth measure) is derived from AccountAbility, a global organization that sets standards for corporate responsibility and sustainable development (www.accountability.org). This organization provides a country-level responsibility index measure that describes the comparative performance of countries in providing an enabling environment for responsible business practices in the future (Resplndex). Higher values for this index reflect more accountable countries. Thus, we predict a positive relationship between Resplndex and CSR disclosure.

The next measure of societal concern (our sixth measure) is constructed using data provided by Yale Law School (http://epi.yale.edu/). The Yale Center for Environmental Law and Policy and the Center for International Earth Science Information Network at Columbia University have developed national-scale environmental indices since 1998, producing an environmental performance index for more than 150 countries (EnvrnmtIPerf) that is released every two years. The values for EnvrnmtlPerf can range between 0 and 100 with higher values indicating countries that more strongly pursue environmental policy goals. As such, we expect EnvrnmtIPerf to be positively related to CSR disclosure.

Our final (seventh) measure of societal concern is derived from the Reporters without Borders website (http://en.rsf.org/) and reflects the degree of freedom journalists and media have in more than 170 countries. The values for this measure can range from 0 to 100 with lower values reflecting higher freedom of press. To align the interpretation of this measure with that of the above-mentioned institutional measures, we multiply this measure by -1 before including it in our analysis (PressFree) so that higher values indicate higher freedom of press. We expect a positive relationship between PressFree and CSR disclosure.

Since all the nation-level measures are correlated to some degree, we follow Dhaliwal et al. (2012) and reduce the seven nation-level measures into a single measure (InstStrength). We create this composite measure of nation-level institutions by first ranking countries based on each of the seven individual nation-level institutional measures (RuleLaw, VoiceAcctblty, GovtEff, RespIndex, EnvrnmtIPerf, RegQuality, and PressFree) and then taking the average ranking of each country. In the first stage of our analysis, we include this composite measure in a model that explains CSR disclosure levels. Thus, we provide a formal test of the effect of national institutions on CSR disclosure levels.

The remaining variables, drawn from Clarkson et al. (2008), are defined as follows. Size is the average natural logarithm of total assets (Compustat item AT) over the 2007 and 2008 fiscal years. ROA is the average income before extraordinary items (Compustat item IB) scaled by total assets over the 2007 and 2008 fiscal years. Fin is the average of the sum of change in debt (Compustat item DLC and DLTT) and common equity (Compustat item CEQ) scaled by total assets over the 2007 and 2008 fiscal years. Lev is average debt (Compustat item DLC and DLTT) scaled by total assets (Compustat item AT) over the 2007 and 2008 fiscal years. NewAssets is the average net property, plant and equipment (Compustat item PPENT) scaled by gross property, plant, and equipment (Compustat item PPEGT) over the 
2007 and 2008 fiscal years. CapEx is the average capital expenditure (Compustat item CAPX) scaled by total sales over the 2007 and 2008 fiscal years. We include industry indicators to control for industry fixed effects, and since we have data from multiple countries, we include country indicators to control for country fixed effects.

We use $\alpha_{1}$ in Equation (1) to test Hypothesis 1, and save the signed residual from Equation (1) as a measure of the unexpected or abnormal component of CSR disclosure (AbCSR). We use AbCSR to test Hypothesis 2 and Hypothesis 3 in a second stage of the analysis. We also include the predicted value from Equation (1) in our second stage analysis to control for the impact of the normal component of CSR disclosure (NormCSR). Following Jiao (2011), in the second stage, we examine the relation between AbCSR and firm value, $Q$, by estimating the following model:

$$
\begin{aligned}
Q= & B_{0}+b_{1} \text { AbCSR }+B_{2} \text { NormCSR }+B_{3} \text { LogMktCap }+b_{4} \text { StockTurn }+b_{5} \text { RetAssets }+B_{6} \text { CapX } \\
& +{ }_{7} \text { Debt }+b_{8} \text { Div }+b_{9} \text { Intang }+b_{10} \text { R7D }+b_{11} \text { RetVol }+\varepsilon,
\end{aligned}
$$

where $Q$ is Tobin's $Q$, as proxied by the market value of assets (Compustat item AT - item $\mathrm{CEQ}+$ [item PRCC_F $x$ item CSHO]) scaled by book value of total assets (item AT). ${ }^{9} B_{1}$ is the coefficient of interest in testing Hypothesis 2; if CSR disclosures are value relevant and socially responsible behavior is valued by the market, $B_{1}$ will be positive.

Our control variables in Equation (2) are drawn from Coles, Daniel, and Naveen (2008) and Roll, Schwartz, and Subrahmanyam (2009). LogMktCap is the natural logarithm of firm market capitalization (Compustat item PRCC_F $x$ item CSHO). StockTurn is the annual share turnover in the underlying stock over the period 2007 to 2008. RetAssets is income before extraordinary items (Compustat item IB) scaled by total assets (Compustat item AT). CapX is capital expenditure (Compustat item CAPX) scaled by total assets (Compustat item AT). Debt is total debt (Compustat item DLC and DLTT) scaled by total assets (Compustat item AT). Div equals 1 if the firm pays a dividend (Compustat item DVC), and 0 otherwise. Intang is one minus the ratio of net property, plant, and equipment (Compustat item PPENT) to total assets (Compustat item AT). R\&D equals 1 if the firm's R\&D (Compustat item XRD) intensity is in the top quartile, and 0 otherwise. RetVol is the standard deviation of daily stock return over the period 2007 to 2008.

\section{Results}

\subsection{Descriptive Statistics}

Panel A of Table 2 reports descriptive statistics for the variables in Equation (1). The mean of CSRDisc is 24.217 and the median is 23.000 which indicate that, in general, firms in our sample disclose less $30 \%$ of the 87 items covered by the KPMG survey. However, the range is substantial with a minimum score of 0 and a maximum of 74 . 
Table 2. Descriptive statistics

\begin{tabular}{|c|c|c|c|c|c|c|c|c|}
\hline \multicolumn{9}{|c|}{ Panel A: Equation (1) variables } \\
\hline & \multicolumn{2}{|c|}{ Full sample $(n=676)$} & \multicolumn{2}{|c|}{ Low disc. sample $(n=331)$} & \multicolumn{3}{|c|}{$\begin{array}{l}\text { High disc. sample } \\
\qquad(n=345)\end{array}$} & \multirow{2}{*}{$\begin{array}{c}\text { Test of } \\
\text { differences } \\
t \text {-Stat. }\end{array}$} \\
\hline & Mean & Median & Mean & Median & Me & $\operatorname{an}$ & Median & \\
\hline CSRDisC & 24.217 & 23.000 & 9.831 & 9.000 & 38. & 017 & 37.000 & $42.17 * * *$ \\
\hline RuleLaw & 1.284 & 1.610 & 1.187 & 1.610 & 1.3 & 78 & 1.380 & $3.52 * * *$ \\
\hline VoiceAcctblty & 1.110 & 1.110 & 1.074 & 1.110 & 1.1 & 44 & 1.110 & $2.52 * *$ \\
\hline GovtEff & 1.463 & 1.650 & 1.426 & 1.650 & 1.4 & 98 & 1.450 & 1.59 \\
\hline RegQuality & 1.278 & 1.390 & 1.234 & 1.520 & 1.3 & 21 & 1.210 & $2.39 * *$ \\
\hline Resplndex & 69.450 & 69.600 & 68.876 & 69.600 & 70. & 000 & 69.600 & $2.16^{* *}$ \\
\hline EnvrnmtlPerf & 83.738 & 84.200 & 83.071 & 82.700 & 84.3 & 377 & 84.500 & $2.70 * * *$ \\
\hline PressFree & -7.807 & -6.500 & -9.064 & -7.670 & -6 & 600 & -6.500 & $3.87^{* * *}$ \\
\hline Size & 9.081 & 9.049 & 8.440 & 8.343 & 9.6 & 96 & 9.795 & $11.07^{* * *}$ \\
\hline ROA & 0.043 & 0.039 & 0.047 & 0.042 & 0.0 & 38 & 0.033 & -1.43 \\
\hline Fin & 0.075 & 0.050 & 0.084 & 0.050 & 0.0 & 67 & 0.050 & -1.23 \\
\hline Lev & 0.297 & 0.268 & 0.284 & 0.244 & 0.3 & 09 & 0.279 & $1.66^{*}$ \\
\hline New Assets & 0.533 & 0.522 & 0.549 & 0.527 & 0.5 & 18 & 0.514 & $-2.68 * * *$ \\
\hline CapEx & 0.139 & 0.053 & 0.181 & 0.040 & 0.0 & 99 & 0.064 & 0.80 \\
\hline \multicolumn{9}{|c|}{ Panel B: Mean of InstStrength and CSRDisc by country } \\
\hline \multicolumn{3}{|c|}{ Country $\quad$ No. of firms } & InstStrength & \multicolumn{2}{|c|}{ CSRDisc } & \multicolumn{2}{|c|}{ EnvCSRDisc } & NonEnvCSRDisc \\
\hline \multicolumn{2}{|l|}{ Sweden } & 22 & 19.857 & \multicolumn{2}{|c|}{29.636} & \multicolumn{2}{|c|}{6.409} & 23.227 \\
\hline \multicolumn{2}{|l|}{ Norway } & 24 & 19.286 & \multicolumn{2}{|c|}{21.333} & \multicolumn{2}{|c|}{6.000} & 15.333 \\
\hline \multicolumn{2}{|l|}{ Denmark } & 22 & 19.071 & \multicolumn{2}{|c|}{16.591} & \multicolumn{2}{|c|}{3.545} & 13.045 \\
\hline \multicolumn{2}{|l|}{ Finland } & 36 & 18.643 & \multicolumn{2}{|c|}{18.222} & \multicolumn{2}{|c|}{4.667} & 13.556 \\
\hline \multicolumn{2}{|l|}{ Switzerland } & 35 & 18.286 & \multicolumn{2}{|c|}{20.543} & \multicolumn{2}{|c|}{3.629} & 16.914 \\
\hline Canada & & 24 & 16.786 & 20 & 58 & & & 15.500 \\
\hline UK & & 58 & 15.786 & 28 & & & & 21.759 \\
\hline Netherlands & & 22 & 15.143 & 27 & 55 & & & 22.182 \\
\hline Australia & & 30 & 14.429 & 22 & & & & 16.500 \\
\hline France & & 38 & 12.357 & 25 & 21 & & & 19.842 \\
\hline USA & & 80 & 11.071 & 23 & 25 & & & 16.688 \\
\hline Portugal & & 15 & 10.857 & 30 & 33 & & & 24.133 \\
\hline Japan & & 79 & 10.357 & 34 & 13 & & & 26.570 \\
\hline Spain & & 18 & 9.429 & 50 & 78 & & & 41.722 \\
\hline Hungary & & 1 & 8.571 & 47 & 00 & & & 40.000 \\
\hline Czech Republi & & 6 & 7.571 & & & & & 4.667 \\
\hline Italy & & 19 & 6.714 & 23 & 58 & & & 17.895 \\
\hline South Korea & & 51 & 6.214 & 22 & 37 & & & 19.039 \\
\hline South Africa & & 51 & 4.857 & 16 & 69 & & & 15.216 \\
\hline Brazil & & 19 & 3.143 & 22 & 47 & & & 18.632 \\
\hline Mexico & & 26 & 2.357 & & & & & 5.308 \\
\hline
\end{tabular}

Notes: in Panel A, CSRDisc is the total CSR disclosure quality score. The 'Low disc.' sample consists of firms with CSR disclosure scores (CSRDisc values) at or below the sample mean. The 'High disc.' sample consists of firms 
with CSRDisc values above the sample mean. See Table 1 for variable definitions of country-level variables. Size is the average natural logarithm of total assets (Compustat item AT) over the 2007 and 2008 fiscal years. ROA is the average income before extraordinary items (Compustat item IB) scaled by total assets over the 2007 and 2008 fiscal years. Fin is the average of the sum of change in debt (Compustat item DLC and DLTT) and common equity (Compustat item CEQ) scaled by total assets over the 2007 and 2008 fiscal years. Lev is the average debt (Compustat item DLC and DLTT) scaled by total assets (Compustat item AT) over the 2007 and 2008 fiscal years. NewAssets is the average net property, plant and equipment (Compustat item PPENT) scaled by gross property, plant and equipment (Compustat item PPEGT) over the 2007 and 2008 fiscal years. CapEx is the average capital expenditure (Compustat item CAPX) scaled by total sales over the 2007 and 2008 fiscal years. In Panel B, InstStrength is a composite measure of nation-level institutional strength that is equal to the mean of the ranks of RuleLaw, VoiceAcctblty, GovtEff, Resplndex, Envrnmtl Perfmnce, Reg Quality, and PressFree for each country. Panel B provides the number of observations and the means for CSRDisc, InstStrength, environmental CSR disclosure scores (EnvCSRDisc), and non-environmental CSR disclosure scores (NonEnvCSRDisc) by country.

Panel A also reports the summary statistics for firms with a CSR disclosure score at or below the median ('Low disc. sample') and above the median ('High disc. sample'). Results from tests of differences between the subsamples indicate that, consistent with our expectations, firms in the high disclosure sample are from countries that have strong enforcement (RuleLaw), greater participation in government selection (VoiceAcctblty), higher regulatory quality (RegQuality), more accountability (RespIndex), a more progressive environmental agenda (EnvrnmtIPerf), and a freer press (PressFree). Among the control variables, we find that firms with higher levels of CSR disclosure are larger in size $(p<0.01)$, more highly levered $(p<0.10)$, and have older assets $(p<0.01)$ than firms with low levels of CSR disclosures.

Panel B of Table 2 shows the number of observations per country, each country's composite nation-level institutional strength score, and the mean of CSRDisc in each country. We also report the mean environmental CSR disclosure score (EnvCSRDisc), and non-environmental CSR disclosure score (NonEnvCSRDisc) of firms by country. The number of firms per country varies from 80 (US) to 1 (Hungary). As mentioned above, we lose observations because of limits in the coverage of Compustat and because the KPMG sample includes private firms as well as public firms. Panel B indicates that Scandinavian countries have the highest nationlevel institutional scores while Central and South American countries have the lowest.

Table 3 reports Pearson and Spearman correlation matrices for variables in Equation (1). The Pearson correlations indicate that CSRDisc is positively correlated with RuleLaw, VoiceAcctblty, RegQuality, Resplndex, EnvrnmtIPerf, and PressFree. Further, all seven nation-level measures of institutional strength are positively correlated with each other, with the correlation coefficients ranging from 0.306 to 0.963 . Because there are a number of significant correlations between the country-level measures, in subsequent analyses, we either analyze the measures independently or use the composite measure (InstStrength) described earlier. 
Table 3. Correlations for variables in Equation (1)

\begin{tabular}{|c|c|c|c|c|c|c|c|c|c|c|c|c|c|c|}
\hline Varia & ) & (2) & 3) & (4) & (5) & (6) & (7) & (8) & (9) & (10) & (11) & (12) & (13) & (14) \\
\hline (1) CSRDisc & & 0.020 & 0.026 & $\begin{array}{l}-0.00 \\
9\end{array}$ & 0.079 & 0.050 & 0.101 & 0.036 & 0.468 & $\begin{array}{l}-0.06 \\
4\end{array}$ & $\begin{array}{l}-0.01 \\
0\end{array}$ & 0.110 & $\begin{array}{l}-0.08 \\
8\end{array}$ & 0.274 \\
\hline (2) RuleLaw & 0.150 & & 0.920 & 0.991 & 0.871 & 0.929 & 0.617 & 0.856 & $\begin{array}{l}-0.02 \\
0\end{array}$ & 0.001 & 0.043 & 0.009 & $\begin{array}{l}-0.18 \\
5\end{array}$ & $\begin{array}{l}-0.12 \\
5\end{array}$ \\
\hline $\begin{array}{l}\text { (3) } \\
\text { VoiceAcctbl } \\
\text { ty }\end{array}$ & 0.118 & 0.903 & & 0.901 & 0.849 & 0.899 & 0.606 & 0.881 & $\begin{array}{l}-0.08 \\
4\end{array}$ & 0.029 & 0.078 & 0.053 & $\begin{array}{l}-0.20 \\
0\end{array}$ & $\begin{array}{l}-0.09 \\
0\end{array}$ \\
\hline (4) GovtEff & 0.064 & 0.963 & 0.850 & & 0.866 & 0.927 & 0.584 & & $\begin{array}{l}-0.03 \\
3\end{array}$ & 0.019 & 0.034 & $\begin{array}{l}-0.02 \\
1\end{array}$ & $\begin{array}{l}-0.1 \\
9\end{array}$ & $\begin{array}{l}-0.14 \\
3\end{array}$ \\
\hline $\begin{array}{l}\text { (5) } \\
\text { RegQuality }\end{array}$ & 0.108 & 0.931 & 0.884 & 0.904 & & 0.919 & & & 0.085 & 0.027 & 0.026 & 0.037 & $\begin{array}{l}-0.13 \\
4\end{array}$ & $\begin{array}{l}-0.14 \\
4\end{array}$ \\
\hline $\begin{array}{l}\text { (6) } \\
\text { RespIndex }\end{array}$ & 0.079 & 0.910 & 0.893 & 0.917 & 0.898 & & & & 0.009 & $\begin{array}{l}-0.01 \\
1\end{array}$ & & 0.040 & $\begin{array}{l}-0.16 \\
0\end{array}$ & $\begin{array}{l}-0.11 \\
8\end{array}$ \\
\hline $\begin{array}{l}\text { (7) } \\
\text { EnvrnmtlPer } \\
f\end{array}$ & 0.102 & 0.617 & 0.625 & 0.552 & 0.521 & 0.591 & & & & $\begin{array}{l}-0.11 \\
7\end{array}$ & & 0.067 & $\begin{array}{l}-0.22 \\
9\end{array}$ & 0.009 \\
\hline $\begin{array}{l}\text { (8) } \\
\text { PressFree }\end{array}$ & 0.182 & 0.732 & 0.763 & 0.673 & 0.578 & 0.664 & 0.306 & & $\begin{array}{l}-0.17 \\
7\end{array}$ & $\begin{array}{l}-0.03 \\
3\end{array}$ & 0.142 & 0.058 & 0.234 & $\begin{array}{l}-0.03 \\
5\end{array}$ \\
\hline (9) Size & 0.438 & 0.202 & 0.038 & 0.095 & 0.168 & 0.030 & 0.092 & 0.034 & & $\begin{array}{l}-0.16 \\
0\end{array}$ & $\begin{array}{l}-0.17 \\
0\end{array}$ & 0.105 & $\begin{array}{l}-0.09 \\
1\end{array}$ & 0.140 \\
\hline (10) ROA & $\begin{array}{l}-0.03 \\
0\end{array}$ & $\begin{array}{l}-0.12 \\
2\end{array}$ & $\begin{array}{l}-0.04 \\
0\end{array}$ & $\begin{array}{l}-0.08 \\
5\end{array}$ & $\begin{array}{l}-0.07 \\
2\end{array}$ & $\begin{array}{l}-0.05 \\
4\end{array}$ & $\begin{array}{l}-0.17 \\
3\end{array}$ & $\begin{array}{l}-0.00 \\
0\end{array}$ & $\begin{array}{l}-0.15 \\
5\end{array}$ & & 0.290 & $\begin{array}{l}-0.28 \\
6\end{array}$ & 0.072 & 0.107 \\
\hline (11) Fin & $\begin{array}{l}-0.00 \\
6\end{array}$ & $\begin{array}{l}-0.02 \\
3\end{array}$ & 0.042 & $\begin{array}{l}-0.01 \\
4\end{array}$ & $\begin{array}{l}-0.01 \\
3\end{array}$ & 0.017 & $\begin{array}{l}-0.04 \\
1\end{array}$ & 0.059 & $\begin{array}{l}-0.16 \\
4\end{array}$ & 0.203 & & 0.284 & 0.193 & 0.247 \\
\hline (12) Lev & 0.092 & 0.030 & 0.061 & $\begin{array}{l}-0.01 \\
3\end{array}$ & 0.023 & 0.024 & 0.039 & 0.084 & 0.086 & $\begin{array}{l}-0.22 \\
1\end{array}$ & 0.515 & & 0.160 & 0.308 \\
\hline $\begin{array}{l}(13) \\
\text { NewAssets }\end{array}$ & $\begin{array}{l}-0.10 \\
1\end{array}$ & $\begin{array}{l}-0.21 \\
5\end{array}$ & $\begin{array}{l}-0.20 \\
8\end{array}$ & $\begin{array}{l}-0.17 \\
8\end{array}$ & $\begin{array}{l}-0.16 \\
9\end{array}$ & $\begin{array}{l}-0.18 \\
8\end{array}$ & $\begin{array}{l}-0.22 \\
1\end{array}$ & $\begin{array}{l}-0.13 \\
0\end{array}$ & $\begin{array}{l}-0.10 \\
6\end{array}$ & 0.060 & 0.246 & 0.215 & & 0.236 \\
\hline (14) CapEx & $\begin{array}{l}-0.04 \\
4\end{array}$ & 0.034 & 0.047 & 0.033 & 0.004 & 0.032 & 0.060 & 0.034 & $\begin{array}{l}-0.09 \\
3\end{array}$ & $\begin{array}{l}-0.21 \\
5\end{array}$ & 0.097 & 0.079 & 0.133 & \\
\hline
\end{tabular}

Notes: Pearson (Spearman) correlation coefficients are presented below (above) the diagonal. Significant correlations ( 0.01 level) in bold. See Tables 1 and 2 for variable definitions.

\subsection{Results for Hypothesis 1}

Table 4 reports the results for Equation (1) where we regresses CSRDisc on the individual nation-level institutional measures and the control variables. Recall that we employ seven different country-level measures in our study. While we use the composite measure to compute the unexpected component of CSR disclosure, we report the results for the individual measures as well. The regression results based on each of the separate countrylevel measures are reported in columns 1-7 of Table 4. 
Table 4. Results for Equation (1) - regression of CSR disclosure on firm- and nation-level variables

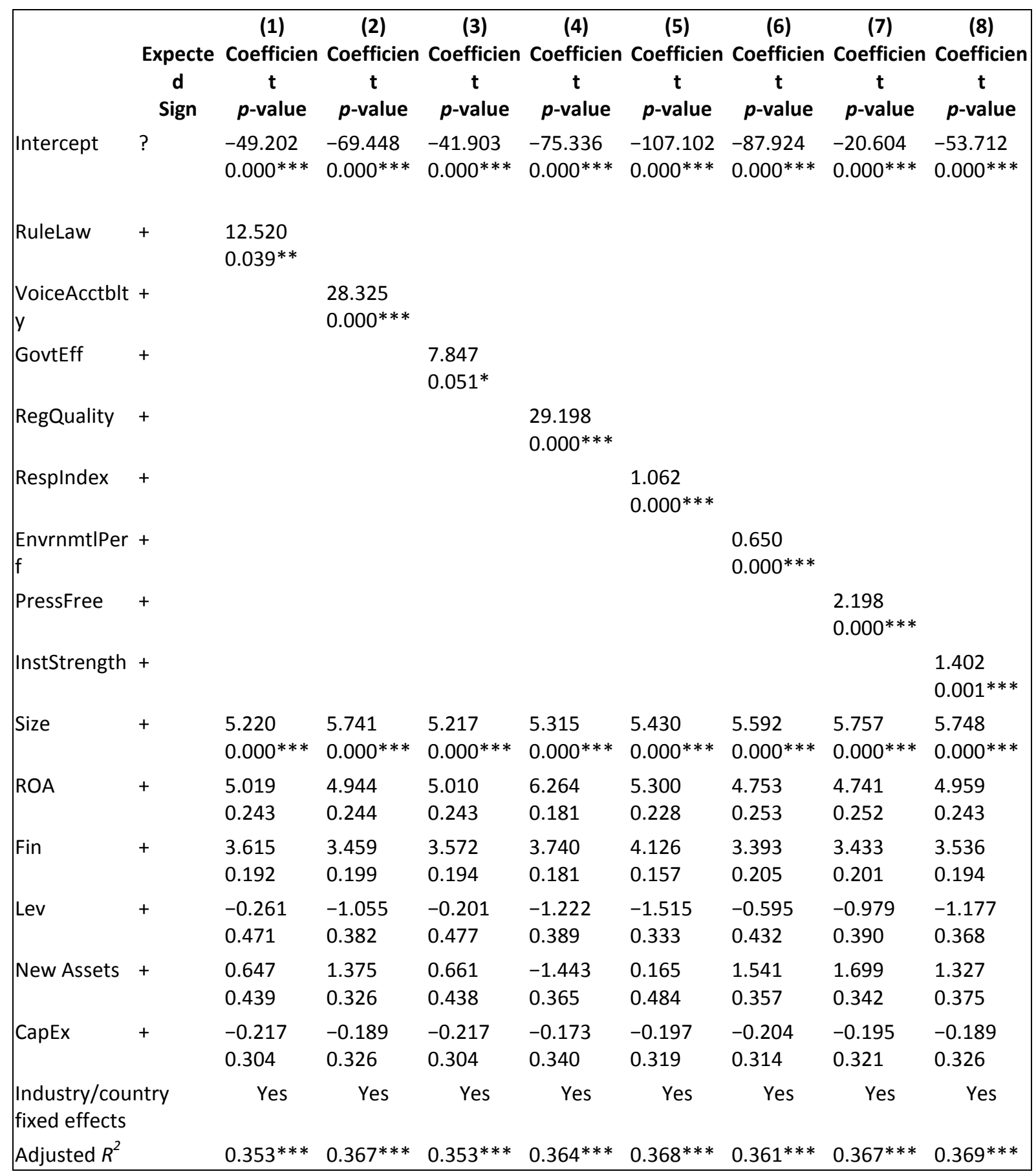

Notes: sample size is 676 firms. The dependent variable is CSR_Disc which is the total CSR disclosure quality score. InstStrength is a composite measure of nation-level institutional strength that is equal to the mean of the ranks of RuleLaw, VoiceAcctblty, GovtEff, Resplndex, EnvrnmtIPerf, RegQuality, and PressFree. See Table 1 for variable definitions of these country-level variables. Size is the average natural logarithm of total assets (Compustat item AT) over the 2007 and 2008 fiscal years. ROA is the average income before extraordinary items (Compustat item IB) scaled by total assets over the 2007 and 2008 fiscal years. Fin is the average of the sum of change in debt (Compustat item DLC and DLTT) and common equity (Compustat item CEQ) scaled by total assets over the 2007 and 2008 fiscal years. Lev is the average debt (Compustat item DLC and DLTT) scaled by total assets (Compustat item AT) over the 2007 and 2008 fiscal years. NewAssets is the average net property, plant and equipment (Compustat item PPENT) scaled by gross property, plant and equipment 
(Compustat item PPEGT) over the 2007 and 2008 fiscal years. CapEx is the average capital expenditure (Compustat item CAPX) scaled by total sales over the 2007 and 2008 fiscal years.

*Significance at the $10 \%$ level.

**Significance at the $1 \%$ level.

$* * *$ Significance at the $1 \%$ level.

The results for the seven nation-level institutional measures are all consistent with Hypothesis 1 , that is, they are positively and significantly related to CSRDisc $(p<0.10)$. This indicates that CSR disclosure is generally higher in countries that have: a stronger enforcement environment, RuleLaw (column 1); higher participation in government selection, VoiceAcctblty (column 2); more effective governments, GovtEff (column 3); higher regulatory quality, RegQuality (column 4); greater accountability, Resplndex (column 5); stronger environmental agenda, EnvrnmtIPerf (column 6); and a freer press, PressFree (column 7).

The results for the control variables indicate that firm size (Size) is positively associated with CSRDisc $(p<0.01)$ across all the regression analyses reported in Table 4 . The adjusted $R^{2}$ of the regression analyses range between $35.3 \%$ and $36.8 \%$, suggesting that our independent variables collectively capture a substantial variation in our CSR disclosure measure. Thus, Table 4 provides support for Hypothesis 1. To our knowledge, ours is the first test to examine the effect of nation-level institutional factors on CSR disclosures in a broad, international sample.

\subsection{Results for Hypothesis 2}

To assess the value relevance of CSR disclosures, we use a two-step process as described above. First, we estimate the unexpected (expected or normal) component of CSR disclosure, AbCSR (NormCSR), as the residual (predicted value) from Equation (1) when the overall nation-level institutional measure (InstStrength) is included, and second, we examine the relation between firm value and both AbCSR and NormCSR by estimating Equation (2).

The results for Equation (1) where InstStrength is included are shown in column 8 of Table 4. InstStrength is positively and significantly associated with CSRDisc at the $1 \%$ level. The adjusted $R^{2}$ of Equation (1) in column 8 is $36.9 \%$. By comparison, our $36.9 \%$ exceeds the mean of $23.2 \%$ reported by Jones (1991, Table 4), who models the predicted (nondiscretionary) portion of accruals, and is comparable to the $37.2 \%$ reported by Core, Holthausen, and Larcker (1999, Table 2), who model predicted CEO compensation.

We expect AbCSR to reflect the unexpected or discretionary part of CSR disclosure and to contain the most useful information for evaluating firms' CSR performance cross-sectionally. If CSR disclosures are informative, we expect to find a positive association between AbCSR and firm value $(Q)$ if CSR disclosures are credible. On the other hand, if CSR disclosures are opportunistic, AbCSR will be uninformative noise. 
We commence our analysis by examining the relationship between total CSR disclosures (CSRDisc) and firm value $(Q)$. The results from this analysis, presented in column 1 of Table 5 , indicate a positive and significant $(p<0.05)$ relationship between CSRDisc and $Q$.

Table 5. Results for Equation (2) - regression of firm value on unexpected CSR disclosure, expected CSR disclosure, nation-level institutions, and control variables

\begin{tabular}{|c|c|c|c|c|}
\hline Variable & $\begin{array}{c}(1) \\
\text { Coefficient } \\
p \text {-value }\end{array}$ & $\begin{array}{c}(2) \\
\text { Coefficient } \\
p \text {-value }\end{array}$ & $\begin{array}{c}\text { (3) } \\
\text { Coefficient } \\
p \text {-value }\end{array}$ & $\begin{array}{c}(4) \\
\text { Coefficient } \\
p \text {-value }\end{array}$ \\
\hline Intercept & $\begin{array}{c}-1.470 \\
0.040 * *\end{array}$ & $\begin{array}{l}-1.824 \\
0.078^{*}\end{array}$ & $\begin{array}{l}-4.031 \\
0.002^{*}\end{array}$ & $\begin{array}{c}-4.078 \\
0.004^{* * *}\end{array}$ \\
\hline CSRDisc & $\begin{array}{c}0.023 \\
0.040^{* *}\end{array}$ & & $\begin{array}{c}0.075 \\
0.008^{* * *}\end{array}$ & \\
\hline AbCSR & & $\begin{array}{c}0.037 \\
0.007^{* * *}\end{array}$ & & $\begin{array}{c}0.121 \\
0.001 * * *\end{array}$ \\
\hline NormCSR & & $\begin{array}{c}-0.017 \\
0.242\end{array}$ & & $\begin{array}{l}0.007 \\
0.291\end{array}$ \\
\hline InstStrength & & & $\begin{array}{c}0.295 \\
0.000 * * *\end{array}$ & $\begin{array}{c}0.252 \\
0.002 * * *\end{array}$ \\
\hline CSRDisc*InstStrength & & & $\begin{array}{c}-0.004 \\
0.003 * *\end{array}$ & \\
\hline AbCSR*InstStrength & & & & $\begin{array}{c}-0.007 \\
0.008 * * *\end{array}$ \\
\hline NormCSR*InstStrength & & & & $\begin{array}{c}-0.002 \\
0.277\end{array}$ \\
\hline LogMktCap & $\begin{array}{c}0.343 \\
0.004^{* * *}\end{array}$ & $\begin{array}{c}0.489 \\
0.001^{* * *}\end{array}$ & $\begin{array}{c}0.411 \\
0.006^{* * *}\end{array}$ & $\begin{array}{c}0.573 \\
0.000 * * *\end{array}$ \\
\hline StockTurn & $\begin{array}{c}-0.140 \\
0.041^{* *}\end{array}$ & $\begin{array}{c}-0.149 \\
0.032 * *\end{array}$ & $\begin{array}{c}-0.175 \\
0.013^{* *}\end{array}$ & $\begin{array}{c}-0.181 \\
0.010 * *\end{array}$ \\
\hline RetAssets & $\begin{array}{c}4.718 \\
0.031^{* *}\end{array}$ & $\begin{array}{c}3.656 \\
0.079 *\end{array}$ & $\begin{array}{c}4.949 \\
0.023^{* *}\end{array}$ & $\begin{array}{c}3.801 \\
0.065^{*}\end{array}$ \\
\hline CapX & $\begin{array}{c}4.582 \\
0.024 * *\end{array}$ & $\begin{array}{c}4.977 \\
0.016^{* *}\end{array}$ & $\begin{array}{c}3.102 \\
0.085^{*}\end{array}$ & $\begin{array}{c}3.540 \\
0.059^{*}\end{array}$ \\
\hline Debt & $\begin{array}{c}-4.449 \\
0.000 * * *\end{array}$ & $\begin{array}{c}-4.082 \\
0.000 * * *\end{array}$ & $\begin{array}{c}-4.866 \\
0.000 * * *\end{array}$ & $\begin{array}{c}-4.411 \\
0.000 * * *\end{array}$ \\
\hline Div & $\begin{array}{c}-1.286 \\
0.004^{* * *}\end{array}$ & $\begin{array}{c}-1.265 \\
0.004^{* * *}\end{array}$ & $\begin{array}{c}-1.644 \\
0.000^{* * *}\end{array}$ & $\begin{array}{c}-1.586 \\
0.000^{* * *}\end{array}$ \\
\hline Intang & $\begin{array}{l}1.375 \\
0.104\end{array}$ & $\begin{array}{c}1.417 \\
0.097^{*}\end{array}$ & $\begin{array}{l}0.308 \\
0.388\end{array}$ & $\begin{array}{l}0.447 \\
0.324\end{array}$ \\
\hline$R \& D$ & $\begin{array}{c}0.575 \\
0.098^{*}\end{array}$ & $\begin{array}{c}0.758 \\
0.047^{* *}\end{array}$ & $\begin{array}{l}0.145 \\
0.371\end{array}$ & $\begin{array}{l}0.337 \\
0.225\end{array}$ \\
\hline RetVol & $\begin{array}{l}0.093 \\
0.442\end{array}$ & $\begin{array}{l}0.065 \\
0.459\end{array}$ & $\begin{array}{l}0.232 \\
0.353\end{array}$ & $\begin{array}{l}0.221 \\
0.359\end{array}$ \\
\hline Industry fixed effects & Included & Included & Included & Included \\
\hline Country fixed effects & Included & Included & Included & Included \\
\hline Adjusted $R^{2}$ & 0.072 & 0.077 & 0.124 & 0.131 \\
\hline
\end{tabular}

Notes: sample size is 555 firms. The dependent variable is $Q$ which is Tobin's $Q$ measured as the market value of assets (Compustat item AT - item CEQ + [item PRCC_F x item CSHO]) scaled by book value of total assets (item AT). CSRDisc and InstStrength are defined in Table 2. AbCSR (NormCSR) is estimated as the residual term (predicted value) from the estimation of Equation 1. LogMktCap is the natural logarithm of firm market capitalization (Compustat item PRCC_F $x$ item CSHO). StockTurn is the annual share turnover in the underlying stock over the period 2007-2008. RetAssets is income before extraordinary items (Compustat item IB) scaled 
by total assets (Compustat item AT). CapX is capital expenditure (Compustat item CAPX) scaled by total assets (Compustat item AT). Debt is total debt (Compustat item DLC and DLTT) scaled by total assets (Compustat item AT). Div equals 1 if the firm pays a dividend (Compustat item DVC), and 0 otherwise. Intang is one minus the ratio of net property, plant, and equipment (Compustat item PPENT) to total assets (Compustat item AT). R\&D equals 1 if the firm's R\&D (Compustat item XRD) intensity is greater than the 75th percentile value, and 0 otherwise. RetVol is the standard deviation of stock return over the period 2007-2008.

*Significance at the $10 \%$ level.

**Significance at the $5 \%$ level.

***Significance at the $1 \%$ level.

Column 2 of Table 5 present the results from the estimation of Equation (2), which examines the separate effects of the unexpected and normal components of CSRDisc (AbCSR and NormCSR) on $Q$. We find that the coefficient on AbCSR (NormCSR) is positively (negatively) signed and significant at the $1 \%$ level (insignificant). This indicates that the unexpected portion of CSR disclosures is positively related to firm value, consistent with Hypothesis 2. On the other hand, the insignificant result for NormCSR suggests that firm value is unaffected by CSR disclosures that are expected by investors, consistent with these disclosures having limited incremental information beyond other firm characteristics.

\subsection{Results for Hypothesis 3}

One concern with Equation (2), as initially presented, is that while it does include countrylevel indicators, markets may react differently to CSR news in countries with varying levels of institutional strength. Stated differently, nation-level institutional strength affects not only the level of CSR disclosures, but also the way the market prices that information. Accordingly, we include our composite nation-level measure in an expanded version of Equation (2) in which we interact CSRDisc and InstStrength. This allows the relation between unexpected CSR disclosure and firm value to vary with the strength of institutions at the nation-level. The results in Dhaliwal et al. (2012) suggest that CSRDisc may be more informative in low InstStrength countries, leading to a negative coefficient on the interaction. To the extent that financial information is of higher quality and that alternative sources of nonfinancial information are of better quality and more widely available in high InstStrength countries, CSR disclosure could be relatively less important in this setting. On the other hand, if investors scrutinize firms' disclosures more closely in high InstStrength countries, firms in these countries are less likely to resort to window-dressing and more likely to disclose truthfully. Consequently, the coefficient on the interaction might be positive.

Our results from this analysis are presented in column 3 of Table 5. We find that the coefficient on CSRDisc is positive and significant at the $1 \%$ level, indicating that firm value increases with total CSR disclosure. Further, the coefficient on InstStrength is significantly positive at the $1 \%$ level. Thus, firms in general have higher valuations when InstStrength is strong, reflecting the benefits of stronger nation-level institutions. Finally, we find that the coefficient on the interaction CSRDisc*InstStrength is negative and significant at the $1 \%$ level. This suggests that the positive relation between CSRDisc and InstStrength is less positive as InstStrength increases. 
Column 4 of Table 5 extends this analysis by focusing on how InstStrength influences the impact of the unexpected and normal components of CSR disclosures (AbCSR and NormCSR) on $Q$. Similar to our results for Hypothesis 2 , we find a positive and significant $(p<0.01)$ coefficient on AbCSR and a positive but insignificant coefficient on NormCSR. Further, the coefficient on InstStrength is significantly positive at the $1 \%$ level. We find a negative and significant $(p<0.01)$ coefficient on the interaction AbCSR*InstStrength. This result suggests that the incremental value of unexpected CSR disclosures is relatively lower in countries with strong country-level institutions. Finally, we find that the coefficient on the interaction NormCSR*InstStrength is negative but insignificant, reinforcing the previous finding in column 2 that the expected portion of CSR disclosure is uninformative.

\section{Additional Tests}

\subsection{The Effect of National Culture on the Likelihood of Firms Disclosing CSR}

National culture, as defined and measured by Hofstede (1983), could influence the propensity of firms to disclose CSR information. We argue that the country-level measures we use in our main analyses are more relevant, as they measure directly relevant governance mechanisms and the effectiveness of those mechanisms, instead of relying on more general measures of culture. However, we perform additional tests to provide empirical evidence that our country-level measures are important determinants of CSR disclosure, even after we control for Hofstede's (1983) cultural dimensions. Some of the cultural dimensions are correlated and one, power distance, correlates strongly with our composite country-level measure (InstStrength), therefore multicollinearity concerns limit our options.

We add each of the other three cultural dimensions to the regression reported in the final column of Table 4, one at a time. Institutional strength (InstStrength) remains positively and significantly associated with CSR disclosures in each of these regression. In relation to the findings for the cultural variables, uncertainty avoidance is negatively and significantly $(p<0.01)$ related to CSR disclosure, the coefficient for individualism is positive and significant $(p<0.01)$, and the coefficient for masculinity is negative and not significant. These cultural dimension findings are broadly consistent with the predictions and findings reported in the prior research literature, for example, Hope (2003).

\subsection{Alternative Measures of Nation-Level Institutional Strength}

To investigate whether our findings are sensitive to how we estimate our nation-level institutional strength measure, we test the robustness of our findings after extracting a measure of institutional strength based on a principal component analysis of the seven individual nation-level metrics. This analysis reveals a singular factor with an eigenvalue exceeding 1 (eigenvalue $=5.56$ ), which accounts for around $79.49 \%$ of the variance in the set of variables. All seven individual measures related to nation-level institutions load onto this factor with the factor loadings ranging from 0.66 to 0.98 . We then employ the resulting factor score as our nation-level institutional measure (InstFactor) to repeat our main analyses. The results from these analyses (not tabulated) indicate that InstFactor is positively related to the extent of CSR disclosures. Further, the unexpected CSR disclosure 
measure extracted after employing InstFactor in Equation (1) remains positively associated with Tobin's $Q$. Also, we find that the coefficient on the variable capturing the interaction effect between the new unexpected CSR disclosure measure and InstFactor is negative. These findings are significant at the $1 \%$ level and consistent with our main findings.

We also extend our analyses after repeating our valuation tests in Table 5 based on the seven individual nation-level measures. We run our analyses separately for each measure as some of them are highly correlated with each other. Columns 1-7 of Table 4 shows that all seven individual nation-level institutional measures are positively and significantly $(p<0.10)$ associated with the extent of CSR disclosure. We use the coefficient estimates from each regression to extract seven additional measures of unexpected CSR disclosure in order to test their associations with Tobin's $Q$ (one at a time), and we find that Tobin's $Q$ is positively and significantly $(p<0.01)$ related to all seven additional measures of unexpected CSR disclosure (results not tabulated). Moreover, our Tobin's $Q$ based results indicate negative and significant $(p<0.05)$ coefficients on all variables capturing the interaction effect of these additional measures of unexpected CSR disclosure with the seven individual nation-level institutional measures with one exception: the coefficient on the variable capturing the interaction effect between GovtEff and its corresponding measure of unexpected CSR disclosure is insignificant. Further, none of the interaction effects between normal CSR disclosure and the seven individual nation-level institutional measures are statistically significant. Overall, these results indicate that our main findings are not sensitive to how we measure the strength of nation-level institutions.

\subsection{Financial Opaqueness}

It could be argued that our nation-level test variable is actually capturing the effect of countries' financial reporting opaqueness rather than the strength of the country's institutions. To test the validity of this argument, we repeat our analyses in Tables 4 and 5 after controlling for two measures of financial reporting opaqueness. Our first proxy is country-, industry-, and year-adjusted total scaled accruals based on Bhattacharya, Daouk, and Welker (2003) as computed by Dhaliwal et al. (2012). ${ }^{10}$ Specifically, our test variable, InvCIY, is coded 1 if a firm has country-industry-year-adjusted total scaled accruals lower than the mean, and 0 otherwise. Our second proxy (InvAcc) is an inverted measure of the total scaled accruals as computed in Bhattacharya et al. (2003). Higher values of InvCIY and InvAccruals are expected to capture lower (higher) levels of financial reporting opaqueness (transparency). Our results from Table 4 (not tabulated) show that while InvCIY is insignificantly associated with the extent of CSR disclosure, all seven of our individual nation-level institutional measures and our composite measure (InstStrength) remain positively $(p<0.05)$ associated with the extent of CSR disclosure. The comparative findings based on InvAccruals indicate a significantly positive $(p<0.05)$ relationship between InvAccruals and CSR disclosures. However, we continue to find to positive and significant $(p<0.05)$ coefficients on all of our nation-level institutional measures.

Next, we employ the residuals from the regression that employs both InvCIY and InvAccruals (along with the remaining independent variables) as explanatory variables to extract our measures of unexpected and normal CSR disclosure (AbCSR and NormCSR) and then execute a valuation analysis similar to that in Table 5. We first regress Tobin's $Q$ on AbCSR, NormCSR, 
our first measure of financial reporting opaqueness (InvCIY), variables capturing the interaction effects between InvCIY and both AbCSR and NormCSR, and the controls. We also include InstStrength and the interaction of InstStrength with both AbCSR and NormCSR as additional independent variables. The results from this analysis are reported in Table 6. Consistent with our main results in Table 5, we find that the coefficient of AbCSR (NormCSR) is positive (positive) and significant at the $1 \%$ level (insignificant) and that the coefficient on the interaction, $\mathrm{AbCSR}^{*}$ InstStrength (NormCSR*InstStrength) is negative (negative) and significant at the $5 \%$ level (insignificant). The coefficients on all variables capturing the interactions between the two financial reporting opaqueness measures and AbCSR and NormCSR remain statistically insignificant. These results indicate that our main findings are robust to controlling for financial reporting opaqueness and provide support for the view that our InstStrength measure is not merely a proxy for financial reporting opaqueness.

Table 6. Results for Equation (2) - controlling for financial reporting opaqueness

\begin{tabular}{|c|c|c|}
\hline & FinRepOpaq = InvCIY & FinRepOpaq = InvAcc \\
\hline Variable & (1) Coefficient $p$-value & (2) Coefficient $p$-value \\
\hline \multirow[t]{2}{*}{ Intercept } & -3.813 & -4.719 \\
\hline & $0.022^{* *}$ & $0.005^{* *}$ \\
\hline \multirow[t]{2}{*}{ AbCSR } & 0.104 & 0.118 \\
\hline & $0.007^{* * *}$ & $0.001 * * *$ \\
\hline \multirow[t]{2}{*}{ NormCSR } & 0.009 & 0.047 \\
\hline & 0.430 & 0.172 \\
\hline \multirow[t]{2}{*}{ InstStrength } & 0.291 & 0.311 \\
\hline & $0.009 * * *$ & $0.000 * * *$ \\
\hline \multirow[t]{2}{*}{ FinRepOpaq } & 1.424 & 5.172 \\
\hline & $0.070^{*}$ & $0.037^{*}$ \\
\hline \multirow[t]{2}{*}{ AbCSR*InstStrength } & -0.006 & -0.007 \\
\hline & $0.009 * * *$ & $0.012^{* *}$ \\
\hline \multirow[t]{2}{*}{ NormCSR ${ }^{*}$ InstStrength } & -0.004 & -0.005 \\
\hline & 0.189 & 0.127 \\
\hline \multirow[t]{2}{*}{ AbCSR*FinRepOpaq } & -0.027 & -0.086 \\
\hline & 0.181 & 0.200 \\
\hline \multirow[t]{2}{*}{ NormCSR*FinRepOpaq } & -0.032 & -0.124 \\
\hline & 0.187 & 0.159 \\
\hline \multirow[t]{2}{*}{ LogMktCap } & 0.627 & 0.576 \\
\hline & $0.000 * * *$ & $0.000 * * *$ \\
\hline
\end{tabular}




\begin{tabular}{|c|c|c|}
\hline & FinRepOpaq = InvCIY & FinRepOpaq = InvAcc \\
\hline Variable & (1) Coefficient $p$-value & (2) Coefficient $p$-value \\
\hline \multirow[t]{2}{*}{ StockTurn } & -0.293 & -0.307 \\
\hline & $0.001 * * *$ & $0.001 * * *$ \\
\hline \multirow[t]{2}{*}{ RetAssets } & 4.509 & 4.923 \\
\hline & $0.044 * *$ & $0.031 * *$ \\
\hline \multirow[t]{2}{*}{ CapX } & 3.254 & 2.633 \\
\hline & $0.086^{*}$ & 0.137 \\
\hline \multirow[t]{2}{*}{ Debt } & -4.601 & -4.173 \\
\hline & $0.000 * * *$ & $0.002 * * *$ \\
\hline \multirow[t]{2}{*}{ Div } & -1.692 & -1.650 \\
\hline & $0.000 * * *$ & $0.000 * * *$ \\
\hline \multirow[t]{2}{*}{ Intang } & 0.323 & 0.289 \\
\hline & 0.390 & 0.401 \\
\hline \multirow[t]{2}{*}{$R \& D$} & 0.238 & 0.260 \\
\hline & 0.306 & 0.290 \\
\hline \multirow[t]{2}{*}{ RetVol } & 0.083 & -0.014 \\
\hline & 0.447 & 0.491 \\
\hline Industry fixed effects & Included & Included \\
\hline Country fixed effects & Included & Included \\
\hline Adjusted $R^{2}$ & 0.143 & 0.146 \\
\hline
\end{tabular}

Notes: sample size used for this analysis is $\mathbf{5 2 9}$ firms. The dependent variable is $Q$. FinRepOpaq represents two measures of financial opaqueness. The first measure of financial opaqueness (InvCIY) is measured using country- and industry-adjusted scaled total accruals based on that of Bhattacharya et al. (2003). InvCIY takes the value of 1 if a firm's scaled total accruals is below the corresponding country-industry mean of scaled total accruals, and 0 otherwise. The second measure of financial opaqueness (InvAcc) is the country- and industryadjusted scaled total accruals based on that of Bhattacharya et al. (2003). See Tables 2 and 5 for other variable definitions.

*Significance at the $10 \%$ level.

**Significance at the $5 \%$ level.

$* * *$ Significance at the $1 \%$ level. 
We next split firms into two subsamples based on the values for our financial reporting opaqueness proxies and repeat our analyses separately for these two subsamples. Our main results hold for all subsamples (untabulated).

\subsection{Controlling for CSR Performance}

A potential concern with our main analysis is that CSR performance is an omitted correlated variable and that CSR performance, rather than CSR disclosure, could be driving our results. To address this concern, we collect data from Bloomberg regarding CSR performance. Although prior studies mostly use the KLD STATS database as a source of CSR performance ratings for individual firms (e.g. Dhaliwal et al., 2011), KLD STATS only cover US firms.

Instead, we collect 'ESG' data from Bloomberg which uses similar data sources to KLD STATS to construct the CSR performance ratings for individual firms, except they cover firms on a worldwide basis. Bloomberg ESG data captures standardized cross-sector and industryspecific metrics, including more than 170 fields that collectively cover environmental, social, and governance performance. These areas of performance are broadly in line with the areas covered by the KLD STATS database and thus capture the firm's overall CSR performance. ${ }^{11}$ 11 Although Bloomberg, like KLD, uses corporate reports as an input to their ratings, they However, we are able to obtain Bloomberg ratings for only 470 of the 676 firms (69.5\%) included in the main analysis.

We re-estimate Equation (1) including CSRPerf. Table 7 reports these results. CSR performance is positively and significantly related to CSRDisc $(p<0.01)$, and the adjusted $R^{2}$ increases to $60.7 \%$. However, InstStrength continues to have a positive coefficient that is significant at the $1 \%$ level. Size also has a positive coefficient and remains significantly related to CSRDisc $(p<0.01)$. ROA, which is not significant in the main analysis (Table 4$)$, now has a significant negative coefficient $(p<0.10)$.

Table 7. Results for Equation (1) and (2) - controlling for CSR performance

\begin{tabular}{|lcccc|}
\hline & \multicolumn{2}{c}{ Equation (1) } & \multicolumn{2}{c|}{ Equation (2) } \\
Variable & Coefficient & $\boldsymbol{p}$-value & Coefficient & $\boldsymbol{p}$-value \\
Intercept & -48.383 & $0.000^{* * *}$ & -1.509 & 0.233 \\
InstStrength & 0.916 & $0.008^{* * *}$ & 0.126 & $0.012^{* *}$ \\
Size & 3.464 & $0.000^{* * *}$ & & \\
ROA & -11.398 & $0.047^{* *}$ & & \\
Fin & -1.479 & 0.343 & & \\
Lev & 2.711 & 0.212 & & \\
NewAssets & 4.166 & 0.154 & & \\
CapEx & -3.163 & 0.250 & & \\
AbCSR & & & 0.135 & $0.002^{* * *}$ \\
NormCSR & & & -0.043 & 0.127 \\
CSRPerf & 0.721 & $0.000^{* * *}$ & 0.038 & $0.072^{*}$ \\
AbCSR ${ }^{*}$ InstStrength & & & -0.005 & $0.021^{* *}$ \\
NormCSR ${ }^{*}$ InstStrength & & & -0.001 & 0.245 \\
AbCSR ${ }^{*}$ CSRPerf & & & -0.001 & $0.067^{*}$ \\
NormCSR*CSRPerf & & & 0.000 & 0.264 \\
\hline
\end{tabular}




\begin{tabular}{|c|c|c|c|c|}
\hline \multirow[b]{2}{*}{ Variable } & \multicolumn{2}{|c|}{ Equation (1) } & \multicolumn{2}{|c|}{ Equation (2) } \\
\hline & Coefficient & $p$-value & Coefficient & $p$-value \\
\hline LogMktCap & & & 0.253 & $0.002 * * *$ \\
\hline StockTurn & & & -0.021 & 0.352 \\
\hline RetAssets & & & 4.172 & $0.004^{* * *}$ \\
\hline CapX & & & 0.954 & 0.247 \\
\hline Debt & & & -1.347 & $0.045^{*}$ \\
\hline Div & & & -0.473 & $0.071^{*}$ \\
\hline Intang & & & 0.000 & 0.500 \\
\hline$R \& D$ & & & -0.101 & 0.354 \\
\hline RetVol & & & -0.317 & 0.319 \\
\hline Industry fixed effects & Included & & Included & \\
\hline Country fixed effects & Included & & Included & \\
\hline Adjusted $R^{2}$ & 0.607 & & 0.113 & \\
\hline
\end{tabular}

Notes: sample size used for the Equation (1) analysis is 470 firms. Sample size for the Equation (2) analysis is 389 firms. The dependent variable in Equation (1) is CSRDisc. The dependent variable in Equation (2) is $Q$. CSRPerf is the CSR performance rating from the Bloomberg ESG database. See Tables 2 and 5 for other variable definitions.

*Significance at the $10 \%$ level.

**Significance at the $5 \%$ level.

***Significance at the $1 \%$ level.

Consistent with our previous tests, we use the residual (predicted value) from the expanded Equation (1) as a measure of the abnormal (normal) component of CSR disclosure. We include CSRPerf, as well as AbCSR*CSRPerf and NormCSR*CSRPerf, in Equation (2) to control for the effects of CSR performance in our second stage regression. As seen in the two righthand columns of Table 7, our results for unexpected and normal CSR disclosure are consistent with the main results reported in Table 5, column 4. Specifically, AbCSR continues to have a positive coefficient and is significant at the $1 \%$ level while NormCSR has an insignificant coefficient, consistent with the unexpected portion of CSR disclosure containing value relevant information. Further, similar to Table $5, A b C S R^{*}$ InstStrength has a negative and significant coefficient $(p<0.05)$ while NormCSR*InstStrength is not significant, indicating that unexpected CSR disclosures have less impact in countries with strong institutions while the relation between normal CSR disclosure and firm value is unaffected by institutional strength. Thus, our main results hold when we control for CSR performance in stage 1 and 2 , even though our sample size is reduced by $30.5 \%$.

\subsection{Change Analysis}

To provide evidence of a causal relationship, we consider whether changes in CSR disclosure lead to changes in firm value. To compute the change in CSR disclosure, we utilize the 2011 KPMG survey. However, as mentioned previously, the 2011 survey covers only 15 items compared to the 87 items included in the 2008 survey. Accordingly, we normalize the scores across the two years by selecting those items that appear in both the 2008 survey and 2011 
survey. There are 14 such items. We then compute CSRDisc for 2008 and 2011 using these 14 items in each year, and we compute the change in CSRDisc by subtracting the 2008 CSRDisc score from the 2011 CSRDisc score.

Before estimating a changes model, we conduct several preliminary analyses (untabulated) using our levels specification to ensure that (1) the 2011 CSR scores are similar in substance to the 2008 CSR scores even though they are based on fewer items and (2) using a CSRDisc based on 14 items does not change the tenor of our prior findings. Accordingly, we replicate our main analysis using the CSRDisc based on all 15 items in the 2011 KPMG survey. We have data for 754 firms. In stage 1, we find a positive and significant coefficient for InstStrength $(p<0.01)$, and in stage 2 , we find a positive and significant coefficient for $\operatorname{AbCSR}(p<0.01)$ and a negative and significant coefficient for AbCSR*InstStrength $(p<0.01)$. NormCSR and NormCSR*InstStrength are not significant. Thus, our main results hold using a more recent and more limited survey instrument. Next, we re-estimate stage 1 and 2 using 2008 data and the original sample but with CSRDisc based on the 14 common items. Again, we find positive coefficients for InstStrength and AbCSR and a negative coefficient for AbCSR*InstStrength and all of these coefficients are significant at the $1 \%$ level. NormCSR and NormCSR*InstStrength remain insignificant. Finally, we repeat the analysis using 2011 data but limit CSRDisc to the 14 common items. The results are again qualitatively identical to the main analysis. Thus, we get strong and consistent results in both years even when CSRDisc is limited to 14 items. These analyses give us confidence that the 14 common items are sufficient to capture variations in CSR reporting practices and support our contention that the change in CSRDisc is a meaningful measure of the change in CSR disclosure between 2008 and 2011.

We use Equation (1) to compute the level of AbCSR and NormCSR in 2008 and 2011. We then estimate a changes version of Equation (2) where we use the change in each variable except InstStrength and the fixed effects. We do not use the change for InstStrength since most of the nation-level variables have the same or similar values in 2008 and 2011.

Table 8 provides the results for Equation (2) using a changes specification. We find that $\triangle A b C S R$ is positively and significantly related to the change in firm value, $\Delta Q$, at the $1 \%$ level, indicating the increases in unexpected CSR disclosures are related to increases in firm value. In addition, $\triangle A b C S R^{*}$ InstStrength has a negative and significant coefficient $(p<0.05)$, suggesting that changes in abnormal CSR disclosure have a smaller effect on changes in firm value in countries with strong institutions. These results provide further support for our levels analyses. ${ }^{12}$ 
Table 8. Results for Equation (2) - using change regression specification

\begin{tabular}{|c|c|c|}
\hline & & \\
\hline Variable & Coefficient & $p$-value \\
\hline Intercept & -5.220 & 0.001 \\
\hline InstStrength & 0.431 & $0.001 * * *$ \\
\hline$\triangle \mathrm{AbCSR}$ & 0.652 & $0.003 * * *$ \\
\hline$\Delta$ NormCSR & 1.348 & $0.029 * *$ \\
\hline$\triangle \mathrm{AbCSR} *$ InstStrength & -0.039 & $0.018 * *$ \\
\hline$\Delta$ NormCSR $*$ InstStrength & -0.120 & $0.022 * *$ \\
\hline$\Delta$ LogMktCap & -0.140 & $0.002 * * *$ \\
\hline$\Delta$ StockTurn & 0.163 & 0.405 \\
\hline$\Delta$ RetAssets & -6.589 & $0.074^{*}$ \\
\hline$\Delta$ CapX & 0.929 & 0.410 \\
\hline$\Delta$ Debt & -3.305 & $0.066 *$ \\
\hline$\Delta$ Div & -0.633 & 0.206 \\
\hline$\Delta$ Intang & 6.110 & $0.052 *$ \\
\hline$\Delta R \& D$ & 0.751 & 0.314 \\
\hline$\Delta$ RetVol & -0.619 & 0.420 \\
\hline Industry fixed effects & Included & \\
\hline Country fixed effects & Included & \\
\hline Adjusted $R^{2}$ & 0.113 & \\
\hline
\end{tabular}

Notes: sample size used for this analysis is 371 firms. The dependent variable is $\Delta Q$ which is three-year change in Tobin's $Q$. See Tables 2 and 5 for variable definitions where all changes are computed as the 2008 value subtracted from the 2011 value.

*Significance at the $10 \%$ level.

**Significance at the $5 \%$ level. 
$* * *$ Significance at the $1 \%$ level.

\subsection{Firm Size Effects}

Given that firm size is the only significant firm-level control variable in Table 4, that is, that affects CSR disclosures, we evaluate the sensitivity of our valuation results (Hypotheses 2 and 3) to firm size. We are interested in whether unexpected CSR disclosures are priced only in small firms, only in large firms, or among all firms regardless of size. Therefore, we reestimate the tests in Table 5 after splitting the sample into small and large firms based on the median market capitalization in our sample. The results (not tabulated) indicate that the coefficient of AbCSR is positive and significant at the $5 \%$ level for small firms and positive and significant at the $10 \%$ level for large firms. The results for the expanded analysis also indicate that the coefficient on AbCSR (AbCSR*InstStrength) is positive (negative) and significant at the $1 \%(5 \%)$ level for small firms, and positive (negative) and significant at the $5 \%(10 \%)$ level for large firms. Therefore, our findings prevail among both small and large firms.

\subsection{Country Sensitivity Tests}

We repeat our analyses after excluding each of the following groups one at a time: (1) US firms which are most highly represented in our sample, (2) Japanese firms which are the next most highly represented in our sample, (3) UK firms because CSR disclosures are particularly popular in the UK (KPMG, 2008), (4) firms from the Nordic countries of Finland, Sweden, Norway, and Denmark which have the strongest nation-level institutions in our sample, and (5) countries with less than 20 observations.

We find that the results of each of these analyses (not tabulated) are consistent with our main results.

\subsection{Future Cash Flows and Profitability}

Next, we augment our findings from the Tobin's $Q$ analysis by examining the impact of AbCSR on variables capturing future profitability and cash flow levels. Specifically, we follow Core et al. (1999) and regress three-year ahead ROA on AbCSR, NormCSR, the standard deviation of ROA for the five-year period from 2004 to 2008, average total sales across 2007-2008, and industry and country indicators. We run a similar analysis based on threeyear ahead operating cash flows. The results from these analyses (not tabulated) indicate that AbCSR is positively and significantly $(p<0.05)$ related to both three-year ahead ROA and three-year ahead operating cash flows. In contrast, NormCSR is not significantly related to either measure of economic performance. These results are consistent with our findings based on Tobin's $Q$.

We also consider whether InstStrength moderates the effect of AbCSR on the future profitability and cash flow levels. However, while we find negative coefficients on variables capturing the interactional effect of AbCSR with InstStrength, these results are not statistically significant. 


\subsection{Effect of Industry Sensitivity on CSR Disclosure}

Since a large part of the CSR literature focuses on environmental disclosures (e.g. Cho \& Patten, 2007; Clarkson, Overell, \& Chapple, 2011), we consider whether our results are driven primarily by firms in environmentally or socially sensitive industries, or whether they extend beyond these industries. Because some industries have more visible environmental or social impacts, companies in these industries may feel greater pressure to explain their CSR activities with additional CSR disclosure. We expect firms in socially or environmentally sensitive industries to disclose more unexpected CSR information, especially in countries with superior institutions. We also examine whether our CSR disclosure results are driven by environmental CSR disclosures, non-environmental CSR disclosures, or both.

In Table 4, we estimate Equation (1) controlling for industry fixed effects. In Table 9, we include a single sensitive-industry indicator (Sensitivelnd) and interact it with InstStrength. Following De Villiers, Naiker, and Van Staden (2011), we code Sensitivelnd equal to 1 if a firm operates in an environmentally sensitive industry (SIC code is 800-899, 1000-1099, 1200-1399, 2600-2699, 2800-3099, 3300-3399, and 4900-4999) and 0 otherwise. We expect both Sensitivelnd and the interaction term to be positively correlated with CSR disclosure, the total CSR disclosure score. Since sensitive industries are defined as industries with pronounced environmental or social impacts, we also split the total CSR disclosure measure (the dependent variable) into environmental disclosure and non-environmental disclosure components and examine whether these results hold for environmental disclosures as well as for non-environmental disclosures.

Table 9 presents the results. In columns 1 and 2 in Panel A, we repeat the general result from the final column of Table 4 for ease of comparison. Columns 3 and 4 of Panel A reveal a negative, but insignificant coefficient on Sensitivelnd, but more importantly, a positive and significant $(p<0.05)$ coefficient on InstStrength*Sensitivelnd. Therefore, firms in our sample from countries with better institutions disclose more CSR information when they operate in sensitive industries. Firms with greater impacts (sensitive industries) have more to explain and are inclined to do so, but only in countries with better governance, more democracy and greater freedom, including freedom of the press. Panels $B$ and $C$ show that this result holds, respectively, for CSR disclosures of an environmental nature, as well as for CSR disclosures of a non-environmental nature. 
Table 9. Results for Equation (1) - based on type of CSR disclosure and industry sensitivity

\begin{tabular}{|c|c|c|c|c|}
\hline & \multicolumn{2}{|c|}{ Equation (1) } & \multicolumn{2}{|c|}{ Expanded model } \\
\hline & (1) Coefficient & (2) $p$-value & (3) Coefficient & (4) $p$-value \\
\hline \multicolumn{5}{|c|}{ Panel A: Dependent variable $=$ Total CSR disclosure quality score } \\
\hline InstStrength & 1.402 & $0.001 * * *$ & 1.172 & $0.000 * * *$ \\
\hline Sensitivelnd & & & -2.468 & 0.196 \\
\hline InstStrength*Sensitivelnd & & & 0.473 & $0.015^{* *}$ \\
\hline Other control variables & \multicolumn{2}{|c|}{ Included } & \multicolumn{2}{|c|}{ Included } \\
\hline Adjusted $R^{2}$ & $0.369 * * *$ & \multicolumn{3}{|c|}{$0.377^{* * *}$} \\
\hline \multicolumn{5}{|c|}{ Panel B: Dependent variable $=$ Total environmental CSR disclosure quality score } \\
\hline InstStrength & 0.148 & $0.038^{* *}$ & 0.092 & 0.141 \\
\hline Sensitivelnd & & & -0.210 & 0.389 \\
\hline InstStrength*Sensitivelnd & & & 0.106 & $0.028 * *$ \\
\hline Other control variables & \multicolumn{2}{|c|}{ Included } & \multicolumn{2}{|c|}{ Included } \\
\hline Adjusted $R^{2}$ & $0.356 * * *$ & & \multicolumn{2}{|c|}{$0.368 * * *$} \\
\hline \multicolumn{5}{|c|}{ Panel C: Dependent variable $=$ Total non-environmental CSR disclosure quality score } \\
\hline InstStrength & 1.255 & $0.001 * * *$ & 1.081 & $0.000 * * *$ \\
\hline Sensitivelnd & & & -2.258 & 0.168 \\
\hline InstStrength*Sensitivelnd & & & 0.367 & $0.019 * *$ \\
\hline Other control variables & \multicolumn{2}{|c|}{ Included } & \multicolumn{2}{|c|}{ Included } \\
\hline Adjusted $R^{2}$ & $0.350 * * *$ & & $0.357 * * *$ & \\
\hline
\end{tabular}

Notes: sample size is 676 firms. Panel A provides the results from the estimation of Equation (1) and an expanded version of Equation (1) where the dependent variable is CSRDisc. Panel B provides the results from the estimation of Equation (1) and an expanded version of Equation (1) where the dependent variable is EnvCSRDisc, which is the total environmental CSR disclosure quality score. Panel C provides the results from the estimation of Equation (1) and an expanded version of Equation (1) where the dependent variable is NonEnvCSRDisc, which is the total non-environmental CSR disclosure quality score. InstStrength is defined in Table 2. Sensitivelnd equals 1 if a firm operates in an environmentally sensitive industry (SIC code is 800-899, 1000-1099, 1200-1399, 2600-2699, 2800-3099, 3300-3399, and 4900-4999) and 0 otherwise. Coefficients for the control variables are not reported.

*Significance at the $10 \%$ level.

**Significance at the $5 \%$ level.

***Significance at the $1 \%$ level.

\subsection{Effect of Industry Sensitivity and CSR Disclosure Type on Firm Value}

Building further on our examination of the potential effects of industry sensitivity, we now turn to the value relevance of CSR disclosures, that is, Equation (2). While Table 5 presents the general results, Table 10 contains our examination of whether these general results hold in both sensitive industry and non-sensitive industry firms, as well as whether the unexpected CSR disclosure results are driven by the unexpected environmental disclosure component or the unexpected non-environmental disclosure component. 
Table 10. Results for Equation (2) - based on type of CSR disclosure and industry sensitivity

\begin{tabular}{|c|c|c|c|}
\hline & $\begin{array}{c}\text { Full sample } \\
\text { ( } n=555) \\
(1) \\
\text { Coefficient } \\
p \text {-value }\end{array}$ & $\begin{array}{c}\text { Sensitive } \\
\text { industries } \\
(n=204) \\
(2) \\
\text { Coefficient } \\
p \text {-value }\end{array}$ & $\begin{array}{c}\text { Non-sensitive } \\
\text { industries } \\
(n=351) \\
(3) \\
\text { Coefficient } \\
p \text {-value }\end{array}$ \\
\hline \multicolumn{4}{|c|}{ Panel A: Based on unexpected (total) CSR disclosure quality score } \\
\hline AbCSR & $\begin{array}{c}0.121 \\
0.001^{* * *}\end{array}$ & $\begin{array}{c}0.150 \\
0.012^{* *}\end{array}$ & $\begin{array}{c}0.104 \\
0.016^{* *}\end{array}$ \\
\hline NormCSR & $\begin{array}{l}0.007 \\
0.291\end{array}$ & $\begin{array}{l}0.077 \\
0.183\end{array}$ & $\begin{array}{c}-0.015 \\
0.404\end{array}$ \\
\hline InstStrength & $\begin{array}{c}0.252 \\
0.002^{* * *}\end{array}$ & $\begin{array}{c}0.500 \\
0.002^{* * *}\end{array}$ & $\begin{array}{c}0.195 \\
0.032^{* *}\end{array}$ \\
\hline AbCSR*InstStrength & $\begin{array}{c}-0.007 \\
0.008^{* * *}\end{array}$ & $\begin{array}{c}-0.009 \\
0.047^{* *}\end{array}$ & $\begin{array}{c}-0.005 \\
0.049^{* *}\end{array}$ \\
\hline NormCSR*InstStrength & $\begin{array}{c}-0.002 \\
0.277\end{array}$ & $\begin{array}{l}-0.010 \\
0.083^{*}\end{array}$ & $\begin{array}{l}0.000 \\
0.488\end{array}$ \\
\hline Other control variables & Included & Included & Included \\
\hline Adjusted $R^{2}$ & $0.131^{* * *}$ & $0.117^{* * *}$ & $0.142^{* * *}$ \\
\hline \multicolumn{4}{|c|}{ Panel B: Based on unexpected environmental CSR disclosure quality score } \\
\hline AbEnvCSR & $\begin{array}{c}0.565 \\
0.000^{* * *}\end{array}$ & $\begin{array}{c}0.737 \\
0.002^{* * *}\end{array}$ & $\begin{array}{c}0.529 \\
0.005^{* * *}\end{array}$ \\
\hline NormEnvCSR & $\begin{array}{c}0.332 \\
0.047^{* *}\end{array}$ & $\begin{array}{l}0.414 \\
0.132\end{array}$ & $\begin{array}{l}0.328 \\
0.104\end{array}$ \\
\hline InstStrength & $\begin{array}{c}0.242 \\
0.001^{* * *}\end{array}$ & $\begin{array}{c}0.406 \\
0.009 * * *\end{array}$ & $\begin{array}{c}0.203 \\
0.009 * * *\end{array}$ \\
\hline AbEnvCSR*InstStrength & $\begin{array}{c}-0.034 \\
0.002^{* * *}\end{array}$ & $\begin{array}{c}-0.043 \\
0.015^{* *}\end{array}$ & $\begin{array}{c}-0.032 \\
0.016^{* * *}\end{array}$ \\
\hline NormEnvCSR*InstStrength & $\begin{array}{c}-0.014 \\
0.175\end{array}$ & $\begin{array}{l}-0.029 \\
0.155\end{array}$ & $\begin{array}{c}-0.011 \\
0.285\end{array}$ \\
\hline Other control variables & Included & Included & Included \\
\hline Adjusted $R^{2}$ & $0.138 * * *$ & $0.134 * * *$ & $0.148^{* * *}$ \\
\hline \multicolumn{4}{|c|}{ Panel C: Based on unexpected non-environmental CSR disclosure quality score } \\
\hline AbNonEnvCSR & $\begin{array}{c}0.128 \\
0.003^{* * *}\end{array}$ & $\begin{array}{c}0.151 \\
0.033^{* *}\end{array}$ & $\begin{array}{c}0.111 \\
0.029^{* *}\end{array}$ \\
\hline NormNonEnvCSR & $\begin{array}{c}-0.015 \\
0.399\end{array}$ & $\begin{array}{l}0.081 \\
0.227\end{array}$ & $\begin{array}{c}-0.048 \\
0.267\end{array}$ \\
\hline InstStrength & $\begin{array}{c}0.232 \\
0.005^{* * *}\end{array}$ & $\begin{array}{c}0.489 \\
0.007^{* * *}\end{array}$ & $\begin{array}{c}0.169 \\
0.057^{*}\end{array}$ \\
\hline AbNonEnvCSR*InstStrength & $\begin{array}{c}-0.007 \\
0.019^{* *}\end{array}$ & $\begin{array}{l}-0.009 \\
0.081^{*}\end{array}$ & $\begin{array}{l}-0.006 \\
0.076^{*}\end{array}$ \\
\hline NormNonEnvCSR*InstStrength & $\begin{array}{c}-0.002 \\
0.357\end{array}$ & $\begin{array}{l}-0.013 \\
0.091^{*}\end{array}$ & $\begin{array}{l}0.002 \\
0.389\end{array}$ \\
\hline Other control variables & Included & Included & Included \\
\hline Adjusted $R^{2}$ & $0.128 * * *$ & $0.109 * * *$ & $0.141^{* * *}$ \\
\hline
\end{tabular}

Notes: the dependent variable in Equation (2) is $Q$. Panel A provides the results from the estimation of an expanded version of Equation (2) based on unexpected total CSR disclosure quality score. Panel B provides the 
results from the estimation of an expanded version of Equation (2) based on unexpected environmental CSR disclosure quality score. Panel $\mathrm{C}$ presents the results from the estimation of an expanded version of Equation (2) based on unexpected non-environmental CSR disclosure quality score. Results are presented for the full sample, firms operating in sensitive industries, and firms operating in non-sensitive industries. AbEnvCSR (NormEnvCSR) is estimated as the residual term (predicted value) from the estimation of Equation (1) when the dependent variable is measured as the total environmental CSR disclosure quality score. AbNonEnvCSR (NormNonEnvCSR) is estimated as the residual term (predicted value) from the estimation of Equation (1) when the dependent variable is measured as the total non-environmental CSR disclosure quality score. See Tables 2 and 5 for other variable definitions. Coefficients for the control variables are not reported.

*Significance at the $10 \%$ level.

**Significance at the $5 \%$ level.

***Significance at the $1 \%$ level.

In Column 1 of Panel A, Table 10, we repeat the results from the last column of Table 5 for ease of comparison. Recall that unexpected CSR disclosures are positively and significantly $(p<0.01)$ associated with firm values as measured by Tobin's $Q$, and this relationship is less pronounced in countries with strong nation-level institutions $(p<0.01)$. In column 2 of Panel $A$, both of these relationships hold in the subsample of firms from sensitive industries. Column 3 of Panel A shows that these relationships also hold in the subsample of firms from non-sensitive industries. Therefore, our results are not driven exclusively by firms in sensitive industries.

Our next step in partitioning the sample and variables is to split the effect of the variable capturing unexpected CSR disclosure (AbCSR) into its unexpected environmental CSR disclosure (Panel B) and unexpected non-environmental CSR disclosure components (Panel C). Our general results hold in each of the analyses.

\section{Conclusion}

Kanter (2011) argues that being socially responsible leads to stronger financial performance and allows the firm to establish itself in a leading position. Firms provide information to investors and other stakeholders about their CSR initiatives through CSR disclosures. Indeed, investors and analysts see CSR disclosures as a preferred source of information about firms' CSR (e.g. Radley Yeldar, 2012).

In the current study, we examine how nation-level institutions affect CSR disclosures and consider whether or not these disclosures are value relevant. In the first stage of our analysis, we regress CSR disclosure on a composite measure of the strength of a nation's institutions and firm-specific and industry control variables. We find higher levels of CSR disclosure in countries where nation-level institutions are strong. In the second stage of our analysis, we use the signed residuals (predicted value) from our first-stage model as a measure of unexpected (normal) CSR disclosure, and we regress Tobin's $Q$ on the institutional strength, unexpected CSR disclosure, normal CSR disclosure, interactions between institutional strength and CSR disclosure, and control variables. We find a positive (no) relation between the unexpected (expected) part of CSR disclosure and firm value. We also find that while countries with stronger nation-level institutions promote more CSR 
disclosures, the value of a unit increase in unexpected CSR disclosures is higher in countries with weaker institutions, less democracy, less press freedom, and less commitment to an environmental agenda. These results are robust to controlling for actual CSR performance and apply to total unexpected CSR disclosures, unexpected environmental CSR disclosures, and unexpected non-environmental disclosures in both socially sensitive industries and nonsensitive industries. Finally, we find that an increase in unexpected CSR disclosure is related to an increase in firm value.

Overall, our study contributes to a line of research examining CSR disclosures and economic performance. After more than 30 years of investigation, researchers have been unable to ascertain a distinct relation between CSR disclosures and economic performance. We contribute to the literature by employing international data, using a more comprehensive measure of CSR disclosure, separating CSR disclosure into an expected and unexpected component, and focusing on the effect of CSR on long-term firm value. Our findings suggest that firms with higher unexpected CSR disclosure have higher firm value, suggesting that CSR concerns are pervasive and that unexpected CSR disclosures play a significant role in firm valuation. On the other hand, we find no evidence that expected CSR disclosures are related to firm value. We also show the economic advantage of CSR disclosures to be greater for firms in countries with weaker institutions, suggesting incentives for firms in these countries to provide CSR disclosures that go beyond the market's expectation.

\section{Acknowledgements}

We thank Florin Vasvari (editor) and an anonymous reviewer for their useful suggestions. We appreciate the helpful comments from Peter Clarkson, Mark Cohen, Tim Devinney, Elaine Henry, and seminar participants at Bristol University, Monash University, University of Bath, University of Bologna, University of Burgos, University of Grenoble, University of Queensland, Vanderbilt University, 2012 Annual Conference of the Accounting and Finance Association of Australia and New Zealand, and 2014 AAA International Accounting Section Midyear Meeting for their helpful comments. We thank KPMG for providing us with the CSR data used in this study.

\section{Notes}

${ }^{1}$ We later present evidence consistent with this conjecture. For example, we show that expected levels of CSR disclosures are not significantly associated with firm value.

${ }^{2}$ We provide a more comprehensive discussion of the nature of KPMG's disclosure measure in Section 3.1 below.

${ }^{3}$ Although our focus is on CSR disclosure, we control for CSR performance in our additional analyses, see Section 5.4 .

${ }^{4}$ An alternative argument is that the market can be 'fooled' by opportunistic disclosures in which case a positive relation between CSR disclosure and firm value would not allow us to discriminate between informative and opportunistic disclosures. However, since actual CSR performance can be observed eventually, we do not expect that a firm can fool investors in 
the long-run. In other words, markets cannot be informationally inefficient in the long-run. If they were, all firms would engage in false disclosures on a continuous basis.

${ }^{5}$ KPMG did not publicly state their reason(s) for reducing the number of questions in 2011 compared to 2008. However, based on private correspondence with a senior partner in sustainability at KPMG, the survey questions are reviewed each round and in 2011 the number of questions were reduced. According to the partner, KPMG considers the quality and relevance of the final report, as well as the cost of conducting the survey, when determining the questions to include.

${ }^{6}$ Due to a lack of financial and market data on unlisted firms, it is not possible to include unlisted firms in our sample. We compared the means of CSR disclosures by listed firms in our final sample $($ mean $=24.217)$ and unlisted firms in the KPMG database (mean $=16.910)$ using a $t$-test and find that listed firms in our final sample disclose significantly $(p<0.000)$ higher levels of CSR information. However, care should be taken in interpreting this result as we could not control for factors that influence CSR disclosure policies, for example, size.

${ }^{7}$ An additional advantage of estimating unexpected CSR disclosures is that it reduces the likelihood that our CSR measure is merely a proxy for the firm's overall disclosure policy since the overall disclosure policy will be reflected in the expected, rather than unexpected, part of CSR disclosures.

${ }^{8}$ These results, discussed in Section 5.4, indicate that our conclusions are unchanged when CSR performance is included.

${ }^{9}$ Our findings and conclusions remain unchanged when we use a one-year ahead measure of Tobin's $Q$.

${ }^{10}$ Scaled accruals (Accruals) are computed using balance sheet and income statement information as ( $\triangle \mathrm{DCA}-\triangle \mathrm{DCL}-\triangle \mathrm{DC}$ ash $+\triangle \mathrm{DSTD}-\mathrm{Dep}+\triangle \mathrm{DTP}) / \operatorname{lag}(\mathrm{TA})$, where $\mathrm{DCA}$ is the change in total current assets; $D C L$ is the change in total current liabilities, DCash is the change in cash, DSTD is the change in the current portion of long-term debt included in total current liabilities, Dep is depreciation and amortization expense; DTP is the change in income taxes payable, and $\operatorname{lag}(\mathrm{TA})$ is total assets at the end of the previous year.

${ }^{11}$ Although Bloomberg, like KLD, uses corporate reports as an input to their ratings, they augment this with other formal and informal sources of information including evaluations by the United Nations and media reports.

12 In Table 8, unlike our levels tests, we find a significant positive coefficient for $\triangle$ NormCSR $(p<0.05)$ and a significant negative coefficient $\triangle$ NormCSR ${ }^{*}$ InstStrength $(p<0.01)$, indicating that the changes in the normal portion of CSR disclosure also affect changes in firm value and that this relation is affected by institutional strength. Similar to the way it is more difficult to explain stock returns than stock prices, we conjecture that our models are less precise in predicting a change in CSR disclosure than in predicting the level of CSR disclosure. Thus, $\triangle$ NormCSR may be capturing some of the unexpected change in CSRDisc which would explain the similar results for $\triangle \mathrm{AbCSR}$ and $\triangle$ NormCSR. 


\section{References}

Al-Tuwaijri, S. A., Christensen, T. E., \& Hughes II, K. E. (2004). The relations among environmental disclosure, environmental performance, and economic performance: $A$ simultaneous equations approach. Accounting, Organizations and Society, 29(5-6), 447471. doi: 10.1016/S0361-3682(03)00032-1

Bhattacharya, U., Daouk, H., \& Welker, M. (2003). The world price of earnings opacity. The Accounting Review, 78(3), 641-678. doi: 10.2308/accr.2003.78.3.641

Bialkowski, J., \& Starks, L. T. (2015). SRI funds: Investor demand, exogenous shocks and ESG profiles (Working paper). University of Texas.

Blacconiere, W. G., \& Patten, D. M. (1994). Environmental disclosures, regulatory costs, and changes in firm value. Journal of Accounting and Economics, 18(3), 357-377. doi: 10.1016/0165-4101(94)90026-4

Brown, W., Helland, E., \& Smith, J. (2006). Corporate philanthropic practices. Journal of Corporate Finance, 12(5), 855-877. doi: 10.1016/j.jcorpfin.2006.02.001

Bushman, R., \& Piotroski, J. (2006). Financial reporting incentives for conservative accounting: The influence of legal and political institutions. Journal of Accounting and Economics, 42(1/2), 107-148. doi: 10.1016/j.jacceco.2005.10.005

Cho, C. H., Freedman, M., \& Patten, D. M. (2012). Corporate disclosure of environmental capital expenditures: A test of alternative theories. Accounting, Auditing \& Accountability Journal, 25(3), 486-507. doi: 10.1108/09513571211209617

Cho, C. H., \& Patten, D. M. (2007). The role of environmental disclosures as tools of legitimacy: A research note. Accounting, Organizations and Society, 32(7-8), 639-647. doi: 10.1016/j.aos.2006.09.009

Cho, C. H., Roberts, R. W., \& Patten, D. M. (2010). The language of US corporate environmental disclosure. Accounting, Organizations and Society, 35(4), 431-443. doi: 10.1016/j.aos.2009.10.002

Clarkson, P. M., Fang, X., Li, Y., \& Richardson, G. (2013). The relevance of environmental disclosures: Are such disclosures incrementally informative? Journal of Accounting and Public Policy, 32(5), 410-431. doi: 10.1016/j.jaccpubpol.2013.06.008

Clarkson, P. M., Li, Y., Richardson, G. D., \& Vasvari, F. P. (2008). Revisiting the relation between environmental performance and environmental disclosure: An empirical analysis. Accounting, Organizations and Society, 33(3), 303-327. doi: 10.1016/j.aos.2007.05.003

Clarkson, P. M., Overell, M., \& Chapple, L. (2011). Environmental reporting and its relation to corporate environmental performance. Abacus, 47(1), 27-60. doi: 10.1111/j.1467$6281.2011 .00330 . x$ 
Coles, J. L., Daniel, N. D., \& Naveen, L. (2008). Boards: Does one size fit all? Journal of Financial Economics, 87(2), 329-356. doi: 10.1016/j.jfineco.2006.08.008

Core, J., Holthausen, R., \& Larcker, D. (1999). Corporate governance, chief executive officer compensation, and firm performance. Journal of Financial Economics, 51(3), 371-406. doi: 10.1016/S0304-405X(98)00058-0

Daske, H., Hail, L., Leuz, C., \& Verdi, R. (2008). Mandatory IFRS reporting around the world: Early evidence on the economic consequences. Journal of Accounting Research, 46(5), 1085-1142.

De Villiers, C., Naiker, V., \& Van Staden, C. J. (2011). The effect of board characteristics on firm environmental performance. Journal of Management, 37(6), 1636-1663. doi: 10.1177/0149206311411506

De Villiers, C., \& Van Staden, C. J. (2010). Shareholders' requirements for corporate environmental disclosures: A cross country comparison. The British Accounting Review, 42(4), 227-240. doi: 10.1016/j.bar.2010.08.002

De Villiers, C., \& Van Staden, C. J. (2011). Where firms choose to disclose voluntary environmental information. Journal of Accounting and Public Policy, 30(6), 504-525. doi: 10.1016/j.jaccpubpol.2011.03.005

Dhaliwal, D. S., Li, O. Z., Tsang, A. H., \& Yang, Y. G. (2011). Voluntary non-financial disclosure and the cost of equity capital: The initiation of corporate social responsibility reporting. The Accounting Review, 86(1), 59-100. doi: 10.2308/accr.00000005

Dhaliwal, D. S., Radhakrishnan, S., Tsang, A., \& Yang, Y. G. (2012). Nonfinancial disclosure and analyst forecast accuracy: International evidence on corporate social responsibility disclosure. The Accounting Review, 87(3), 723-759. doi: 10.2308/accr-10218

Doidge, C., Karolyi, G. A., \& Stulz, R. M. (2004). Why are foreign firms listed in the US worth more? Journal of Financial Economics, 71(2), 205-238. doi: 10.1016/S0304-405X(03)00183-1

Edmans, A. (2011). Does the stock market fully value intangibles? Employee satisfaction and equity prices. Journal of Financial Economics, 101(3), 621-640. doi: 10.1016/j.jfineco.2011.03.021

Elliott, W. B., Jackson, K. E., Peecher, M. E., \& White, B. J. (2014). The unintended effect of corporate social responsibility performance on investors' estimates of fundamental value. The Accounting Review, 89(1), 275-302. doi: 10.2308/accr-50577

Fang, L., \& Peress, J. (2009). Media coverage and the cross-section of stock returns. The Journal of Finance, 64(5), 2023-2052. doi: 10.1111/j.1540-6261.2009.01493.x

Fombrun, C., \& Shanley, M.. (1990). What's in a name? Reputation building and corporate strategy. Academy of management Journal, 33(2), 233-258. doi: 10.2307/256324 
Frankel, R., McNichols, M., \& Wilson, P. (1995). Discretionary disclosure and external financing. The Accounting Review, 70(1), 135-150.

Freedman, M., \& Jaggi, B. (1988). An analysis of the association between pollution disclosure and economic performance. Accounting, Auditing \& Accountability Journal, 1(2), 43-58. doi: 10.1108/EUM0000000004623

Healy, P. M., \& Palepu, K. G. (2001). Information asymmetry, corporate disclosure, and the capital markets: A review of the empirical disclosure literature. Journal of Accounting and Economics, 31(1-3), 405-440. doi: 10.1016/S0165-4101(01)00018-0

Hofstede, G. (1983). National cultures in four dimensions: A research-based theory of cultural differences among nations. International Studies of Management \& Organization, 13(1/2), 46-74. doi: 10.1080/00208825.1983.11656358

Hong, H., \& Kacperczyk, M. (2009). The price of sin: The effects of social norms on markets. Journal of Financial Economics, 93(1), 15-36. doi: 10.1016/j.jfineco.2008.09.001

Hope, O.-K. (2003). Firm-level disclosures and the relative roles of culture and legal origin. Journal of International Financial Management and Accounting, 14(3), 218-248. doi: 10.1111/1467-646X.00097

Hughes, S. B., Anderson, A., \& Golden, S. (2001). Corporate environmental disclosures: Are they useful in determining environmental performance? Journal of Accounting and Public Policy, 20(3), 217-240. doi: 10.1016/S0278-4254(01)00031-X

Ingram, R. W., \& Frazier, K. B. (1980). Environmental performance and corporate disclosure. Journal of Accounting Research, 18(2), 614-622. doi: 10.2307/2490597

Ioannou, I., \& Serafeim, G. (2012). What drives corporate social performance? The role of nation-level institutions. Journal of International Business Studies, 43(9), 834-864. doi: 10.1057/jibs.2012.26

Jiao, Y. (2011). Corporate disclosure, market valuation, and firm performance. Financial Management, 40(3), 647-676. doi: 10.1111/j.1755-053X.2011.01156.x

Jones, J. (1991). Earnings management during import relief investigations. Journal of Accounting Research, 29(2), 193-228. doi: 10.2307/2491047

Kanter, R. M. (2011). How great companies think differently. Harvard Business Review, $89(11), 66-78$.

Kaufmann, D., Kraay, A., \& Mastruzzi, M. (2011). The worldwide governance indicators: Methodology and Analytical Issues. Hague Journal on the Rule of Law, 3(2), 220-246. doi: $10.1017 /$ S1876404511200046 
KPMG. (2008). International survey of corporate responsibility reporting. Retrieved from http://www.kpmg.com/Global/IssuesAndInsights/ArticlesAndPublications/Pages/Sustainabil ity-corporate-responsibility-reporting-(2008).aspx

KPMG. (2011). KPMG International survey of corporate responsibility reporting 2011. Retrieved from https://www.kpmg.com/PT/pt/IssuesAndInsights/Documents/corporateresponsibility2011.pdf

Lang, M., \& Maffett, M. (2011). Economic effects of transparency in international equity markets: A review and suggestions for future research. Foundations and Trends in Accounting, 5(3), 175-241. doi: 10.1561/1400000016

Lang, M. H., Lins, K. V., \& Miller, D. P. (2004). Concentrated control, analyst following, and valuation: Do analysts matter most when investors are protected least? Journal of Accounting Research, 42(3), 589-623. doi: 10.1111/j.1475-679X.2004.t01-1-00142.x

Lang, M. H., \& Lundholm, R. J. (1993). Cross-sectional determinants of analyst ratings of corporate disclosures. Journal of Accounting Research, 31(2), 246-247. doi:

$10.2307 / 2491273$

Leftwich, R. W., Watts, R. L. \& Zimmerman, J. L. (1981). Voluntary corporate disclosure: The case of interim reporting. Journal of Accounting Research, 19(Suppl.), 50-77. doi: $10.2307 / 2490984$

Lev, B., Petrovits, C., \& Radhakrishnan, S. (2010). Is doing good good for you? Yes, charitable contributions enhance revenue growth. Strategic Management Journal, 31(2), 182-200.

Marquis, C., \& Qian, C. (2014). Corporate social responsibility reporting in China: Symbol or substance? Organization Science, 25(1), 127-148. doi: 10.1287/orsc.2013.0837

Matsumura, E. M., Prakash, R., \& Vera-Muñoz, S. C. (2014). Firm-value effects of carbon emissions and carbon disclosures. The Accounting Review, 89(2), 695-724. doi: $10.2308 /$ accr-50629

Merkl-Davies, D., \& Brennan, N. (2007). Discretionary disclosure strategies in corporate narratives: Incremental information or impression management? Journal of Accounting Literature, 26, 116-194.

Merton, R. (1987). A simple model of capital market equilibrium with incomplete information. The Journal of Finance, 42(3), 483-510. doi: 10.1111/j.1540-

6261.1987.tb04565.x

Patten, D. M. (1992). Intra-industry environmental disclosures in response to the Alaskan oil spill: A note on legitimacy theory. Accounting, Organizations and Society, 17(5), 471-475. doi: 10.1016/0361-3682(92)90042-Q 
Patten, D. M. (2002). The relation between environmental performance and environmental disclosure: A research note. Accounting, Organizations and Society, 27(8), 763-773. doi: 10.1016/S0361-3682(02)00028-4

Plumlee, M., Brown, D., Hayes, R. M. \& Marshall, R. S. (2015). Voluntary environmental disclosure quality and firm value: Further evidence. Journal of Accounting and Public Policy. Retrieved from http://dx.doi.org/10.1016/j.jaccpubpol.2015.04.004[Web of Science $\left.{ }^{\circledR}\right]$

Radley Yeldar. (2012). The value of extra-financial disclosure: What investors and analysts said. Report commissioned by Accounting for Sustainability and the Global Reporting Initiative. Retrieved from https://www.globalreporting.org/resourcelibrary/The-value-ofextra-financial-disclosure.pdf

Roll, R., Schwartz, E., \& Subrahmanyam, A. (2009). Options trading activity and firm valuation. Journal of Financial Economics, 94(3), 345-360. doi:

10.1016/j.jfineco.2009.02.002

Simnett, R., Vanstraelen, A., \& Chua, W. F. (2009). Assurance on sustainability reports: An international comparison. The Accounting Review, 84(3), 937-967. doi:

10.2308/accr.2009.84.3.937

Verrecchia, R. (1983). Discretionary disclosure. Journal of Accounting and Economics, 5(3), 179-194. doi: 10.1016/0165-4101(83)90011-3

Verrecchia, R. (1990). Information quality and discretionary disclosure. Journal of Accounting and Economics, 12(4), 365-380. doi: 10.1016/0165-4101(90)90021-U

Wiseman, J. (1982). An evaluation of environmental disclosures made in corporate annual reports. Accounting, Organizations and Society, 7(1), 53-63. doi: 10.1016/03613682(82)90025-3 